\title{
Phase Behavior of a United Arab Emirates Stock-Tank Oil and Carbon Dioxide at Reservoir Conditions: Experiments and Thermodynamic Modeling
}

\author{
Samir I. Abu-Eishah*, Rashid S. Mohammad \\ Department of Chemical \& Petroleum Engineering, United Arab Emirates University, Al Ain, UAE \\ Email: "s.abueishah@uaeu.ac.ae, Rashid.s@hotmail.com
}

Received 13 January 2016; accepted 17 April 2016; published 20 April 2016

Copyright (C) 2016 by authors, Yangtze University and Scientific Research Publishing Inc. This work is licensed under the Creative Commons Attribution International License (CC BY). http://creativecommons.org/licenses/by/4.0/

c) (i) Open Access

\begin{abstract}
Injection of a soluble gas like $\mathrm{CO}_{2}$ into an oil reservoir reduces the interfacial tension and oil viscosity and contributes to oil swelling, which together, in turn, enhance the oil mobility and relative permeability. In this work an experimental phase equilibrium setup for the recombination of live oil (stock-tank oil and first-stage separator gas) and measurement of the corresponding phase behaviors of $\mathrm{CO}_{2} /$ live oil mixtures is described. In the recombination process, the vapor-to-oil molar ratio was adjusted until the composition of the original reservoir fluid was obtained. The average of the absolute error (AAE) in composition was about $0.77 \%$ and $1.09 \%$ for the two reservoir fluids under test (named here wells $A \# 22$ and $A \# 33$, respectively). The optimum vapor-tooil molar ratio for zero deviation in the methane composition in the live oil (recombined) was about 0.42 for both wells. In addition, the PVTi simulator was used to reproduce the live oil (by combining the first-stage separator gas and the stock-tank oil) and also to predict the recombined oil characteristics at the reservoirs' saturation pressure and bottom hole temperature. On the other hand, the PVTpro simulator was used to investigate the oil swelling rate and establish the relationship between saturation pressure and the injected $\mathrm{CO}_{2}$ mass fraction. The average of the absolute relative error (AARE) between experimental and predicted saturation pressures was $\mathbf{7 . 7 8 \%}$ for well $A \# 22$ and $\mathbf{5 . 3 8 \%}$ for well $A \# 33$.
\end{abstract}

\section{Keywords}

Crude Oil, Live Oil, Recombined Oil, Swelling Factor, $\mathrm{CO}_{2}$ Injection, Enhanced Oil Recovery

\footnotetext{
${ }^{*}$ Corresponding author.
}

How to cite this paper: Abu-Eishah, S.I. and Mohammad, R.S. (2016) Phase Behavior of a United Arab Emirates Stock-Tank Oil and Carbon Dioxide at Reservoir Conditions: Experiments and Thermodynamic Modeling. Open Journal of Yangtze Oil and Gas, 1, 1-22. http://dx.doi.org/10.4236/ojogas.2016.11001 


\section{Introduction}

Tertiary or enhanced oil recovery processes are associated with the injection of a specific type of fluid or fluids into a reservoir. The fluid injection supplements the natural energy left over in the reservoir and displaces the un-recovered oil. The increased interaction between the injected fluid and the in-place oil results in alterations in rock and fluid properties. Fluid injection and eventual interaction bring about changes like a lowering in interfacial tension, oil swelling, oil viscosity reduction, wettability modification, and sometimes favorable phase behavior conditions. These changes are mainly attributed to physics and chemical interaction between the two fluids and also to the fluid injection rate and pressure [1]. The many advantages of $\mathrm{CO}_{2}$ injection over those of water and nitrogen injection are summarized in [2].

$\mathrm{CO}_{2}$ flooding is among the most promising enhanced oil recovery (EOR) methods in heavy oil reservoirs and has been successfully used in a number of worldwide basins where other EOR techniques are not applicable [3]. $\mathrm{CO}_{2}$ becomes supercritical when injected under reservoir conditions, and as a consequence it can recover more oil with the additional benefit of considerably reducing greenhouse gas emissions. The greatest difference compared to other gases is that $\mathrm{CO}_{2}$ can extract heavier components up to $\mathrm{C}_{30}$. The solubility of $\mathrm{CO}_{2}$ in hydrocarbon oil causes the oil to swell. $\mathrm{CO}_{2}$ expands oil to a greater extent than methane does. The swelling depends on the amount of methane in the oil. Because the $\mathrm{CO}_{2}$ does not displace all of the methane when it contacts a reservoir fluid, the more methane there is in the oil, the less is the swelling of the oil [4].

Several factors that affect the mobilization efficiency are rock geometry, pore structure, flooding rate and fluid properties [5]. During the flooding process, $\mathrm{CO}_{2}$ is injected into the formation to highly enhance the mobility of the contacted oil, thus promoting its displacement towards production. Oil mobility is improved because the solubility of $\mathrm{CO}_{2}$ in the oil increases the oil volume and at the same time causes a reduction in the oil viscosity [5]. Characterization of produced and residual oils in the $\mathrm{CO}_{2}$ flooding process has been recently carried out by [6]. This kind of study provides a deep understanding of the changes of properties of the produced and residual oils in $\mathrm{CO}_{2}$-EOR processes.

The solubility of $\mathrm{CO}_{2}$ in oil fractions constitutes a key factor for EOR successful projects and thus, the study of phase behavior of the $\mathrm{CO}_{2}$ /crude oil system is the first fundamental step for understanding the oil recovery mechanism in petroleum reservoirs. Knowledge about the phase behavior of solvents of low molecular weights (such as $\mathrm{CO}_{2}$ ) and petroleum fluids is important for primary oil production, enhanced oil recovery, gas injection [7] and re-injection [5], pipeline transportation, deasphalting, and petroleum processing and refining [8]. Several literature correlations for $\mathrm{CO}_{2}$-oil physical properties $\left(\mathrm{CO}_{2}\right.$ solubility, oil swelling due to $\mathrm{CO}_{2}, \mathrm{CO}_{2}$-oil density, and $\mathrm{CO}_{2}$-oil viscosity) have been tested by Al-Jarba and Al-Anazi [9] who recommended Emera and Sarma models [10] to be applied over wider data ranges and operating conditions.

Feizabadi et al. [11] observed the formation of a second liquid phase when propane or $\mathrm{CO}_{2}$, was used as solvent, with the second liquid phase mainly composed of the solvent itself. They carried out a research to understand the importance of the second liquid phase and its effect on oil production. They claimed that the allocation of such a liquid phase through a simulator would allow for prediction of the amount of solvent that can be produced and recycled, which makes a more realistic cost evaluation of the solvent injection processes. They added that the relative permeability plays an important role in multiphase flow; numerical results indicated that, by increasing the number of phases, there will be an increase in the project life.

Prior to any $\mathrm{CO}_{2}$-EOR project, meticulous laboratory tests have to be conducted to characterize the phase behavior between $\mathrm{CO}_{2}$ and the reservoir oil. The results of these are very important during the pre-injection phase to establish baseline predictions of $\mathrm{CO}_{2}$ behavior in the reservoir and oil production [12].

In this work, experimental phase transition data of mixtures composed of $\mathrm{CO}_{2}$ and live oil are reported over a pressure range of 150 to $330 \mathrm{bar}$ and a $\mathrm{CO}_{2}$ mass fraction of $w_{\mathrm{CO}_{2}}=0.0$ to 0.6 at the reservoir bottom hole temperature. Increasing $w_{\mathrm{CO}_{2}}$ above 0.6 requires a pressure $>500$ bar in the syringe pump. At $w_{\mathrm{CO}_{2}}=0.6$ no stabilization was observed and no monophasic system was detected.

\section{Field Data and Materials Used}

The Commercial Service Provider collected and analyzed two bottom-hole samples from wells A\#22 and A\#33 in the UAE. The reservoir initial static pressure, bottom hole temperature and bubble point pressure at that temperature are respectively 4687 psia, $235^{\circ} \mathrm{F}$ and 2277 psia for well A\#22 and 2820 psia, $257^{\circ} \mathrm{F}$ and 2377 psia for well A\#33. The API gravity of the stock-tank oil at standard conditions are 37.1 and 36.9 for wells A\#22 and 
A\#33, respectively. The stock-tank oil as supplied has the compositional analysis and characteristics presented in Table 1 and Table 2. The carbon dioxide used in this work was supplied by Air Products Emirates Gas LLC, Dubai (UAE) and has a purity $>99.5 \%$.

\section{Experimental Setup}

The experimental scheme used in this work is based on the static-synthetic method shown in Figure 1. It consists of a high-pressure, variable-volume PVT view cell (made in Brazil), two syringe pumps (ISCO brand, model 260D) and a heating device with magnetic stirrer (Stuart Magnetic Stirrer CC162/SC162). The view cell has two sapphire windows for visual observations, an absolute pressure transducer (Smar, LD 301) with a precision of \pm 0.31 bar, and a portable programmer (Smar, HT 201) for pressure data acquisition. The equilibrium cell

Table 1. Fluid compositions (mol \%) for wells A\#22 and A\#33 as supplied by the commercial service provider ( $p \equiv$ pseudo).

\begin{tabular}{|c|c|c|c|c|c|c|}
\hline \multirow{2}{*}{ Component } & \multicolumn{3}{|c|}{ Well A\#22 } & \multicolumn{3}{|c|}{ Well A\#33 } \\
\hline & Flashed liquid & flashed gas & $\begin{array}{l}\text { Monophasic } \\
\text { fluid }\end{array}$ & Flashed liquid & Flashed gas & $\begin{array}{l}\text { Monophasic } \\
\text { fluid }\end{array}$ \\
\hline $\mathrm{N}_{2}$ & 0.00 & 0.23 & 0.119 & 0.00 & 0.18 & 0.101 \\
\hline $\mathrm{CO}_{2}$ & 0.01 & 3.58 & 1.860 & 0.03 & 4.86 & 2.738 \\
\hline $\mathrm{CH}_{4}$ & 0.06 & 61.09 & 31.692 & 0.08 & 58.58 & 32.858 \\
\hline $\mathrm{C}_{2} \mathrm{H}_{6}$ & 0.15 & 11.80 & 6.188 & 0.25 & 11.73 & 6.682 \\
\hline $\mathrm{C}_{3} \mathrm{H}_{8}$ & 0.60 & 10.54 & 5.752 & 1.05 & 10.72 & 6.468 \\
\hline $\mathrm{i}-\mathrm{C}_{4} \mathrm{H}_{10}$ & 0.37 & 2.24 & 1.339 & 0.57 & 2.39 & 1.590 \\
\hline $\mathrm{n}-\mathrm{C}_{4} \mathrm{H}_{10}$ & 1.38 & 5.23 & 3.375 & 2.06 & 5.62 & 4.055 \\
\hline $\mathrm{i}-\mathrm{C}_{5} \mathrm{H}_{10}$ & 1.36 & 1.65 & 1.510 & 1.73 & 1.88 & 1.814 \\
\hline $\mathrm{n}-\mathrm{C}_{5} \mathrm{H}_{10}$ & 2.27 & 1.92 & 2.089 & 2.90 & 2.24 & 2.530 \\
\hline $\mathrm{p}-\mathrm{C}_{6} \mathrm{H}_{14}$ & 5.51 & 1.14 & 3.245 & 6.56 & 1.27 & 3.596 \\
\hline $\mathrm{p}-\mathrm{C}_{7} \mathrm{H}_{16}$ & 7.31 & 0.46 & 3.760 & 8.42 & 0.43 & 3.943 \\
\hline $\mathrm{p}-\mathrm{C}_{8} \mathrm{H}_{18}$ & 8.08 & 0.11 & 3.949 & 9.33 & 0.09 & 4.153 \\
\hline $\mathrm{p}-\mathrm{C}_{9} \mathrm{H}_{20}$ & 7.42 & 0.01 & 3.579 & 8.49 & 0.01 & 3.739 \\
\hline $\mathrm{p}-\mathrm{C}_{10} \mathrm{H}_{22}$ & 6.96 & 0.00 & 3.353 & 7.61 & 0.00 & 3.346 \\
\hline $\mathrm{p}-\mathrm{C}_{11} \mathrm{H}_{24}$ & 5.73 & 0.00 & 2.760 & 6.13 & 0.00 & 2.695 \\
\hline $\mathrm{p}-\mathrm{C}_{12} \mathrm{H}_{26}$ & 4.92 & 0.00 & 2.370 & 5.00 & 0.00 & 2.199 \\
\hline $\mathrm{p}-\mathrm{C}_{13} \mathrm{H}_{28}$ & 4.77 & 0.00 & 2.298 & 4.50 & 0.00 & 1.979 \\
\hline $\mathrm{p}-\mathrm{C}_{14} \mathrm{H}_{30}$ & 4.94 & 0.00 & 2.380 & 3.74 & 0.00 & 1.644 \\
\hline p- $\mathrm{C}_{15} \mathrm{H}_{32}$ & 4.42 & 0.00 & 2.129 & 3.41 & 0.00 & 1.499 \\
\hline $\mathrm{p}-\mathrm{C}_{16} \mathrm{H}_{34}$ & 4.01 & 0.00 & 1.932 & 2.79 & 0.00 & 1.227 \\
\hline $\mathrm{p}-\mathrm{C}_{17} \mathrm{H}_{36}$ & 3.49 & 0.00 & 1.681 & 2.42 & 0.00 & 1.064 \\
\hline $\mathrm{p}-\mathrm{C}_{18} \mathrm{H}_{38}$ & 3.05 & 0.00 & 1.469 & 2.15 & 0.00 & 0.945 \\
\hline $\mathrm{p}-\mathrm{C}_{19} \mathrm{H}_{40}$ & 2.81 & 0.00 & 1.354 & 2.04 & 0.00 & 0.897 \\
\hline $\mathrm{C}_{20}^{+}$ & 20.38 & 0.00 & 9.817 & 18.75 & 0.00 & 8.244 \\
\hline Molar ratios & 0.4817 & 0.5183 & 1.00 & 0.4397 & 0.5603 & 1.00 \\
\hline
\end{tabular}


Table 2. Some phase properties for wells A\#22 and A\#33 as supplied by the commercial service provider (NA $\equiv$ not available).

\begin{tabular}{|c|c|c|c|c|c|c|}
\hline \multirow[b]{2}{*}{ Properties } & \multicolumn{3}{|c|}{ Well A\#22 } & \multicolumn{3}{|c|}{ Well A\#33 } \\
\hline & Flashed liquid & Flashed gas & $\begin{array}{l}\text { Monophasic } \\
\text { fluid }\end{array}$ & Flashed liquid & Flashed gas & $\begin{array}{l}\text { Monophasic } \\
\text { fluid }\end{array}$ \\
\hline Fluid molar mass (g/mol) & 200.25 & 28.08 & 111.02 & 190.79 & 29.06 & 100.18 \\
\hline $\mathrm{C}_{7}^{+}$molar mass $(\mathrm{g} / \mathrm{mol})$ & NA & -- & NA & 212.16 & 98.34 & 211.26 \\
\hline $\mathrm{C}_{20}^{+}$molar mass $(\mathrm{g} / \mathrm{mol})$ & 403.78 & -- & 403.78 & 424.48 & -- & 424.48 \\
\hline Fluid density $\left(\mathrm{g} / \mathrm{cm}^{3}\right)$ & 0.832 & 0.001185 & -- & 0.828 & 0.001227 & -- \\
\hline $\mathrm{C}_{7}^{+}$density $\left(\mathrm{g} / \mathrm{cm}^{3}\right)$ & NA & -- & NA & 0.843 & -- & 0.842 \\
\hline $\mathrm{C}_{20}^{+}$density $\left(\mathrm{g} / \mathrm{cm}^{3}\right)$ & 0.909 & -- & 0.909 & 0.916 & -- & 0.916 \\
\hline Gas specific gravity, air $=1$ & -- & 0.970 & -- & -- & 1.003 & -- \\
\hline
\end{tabular}

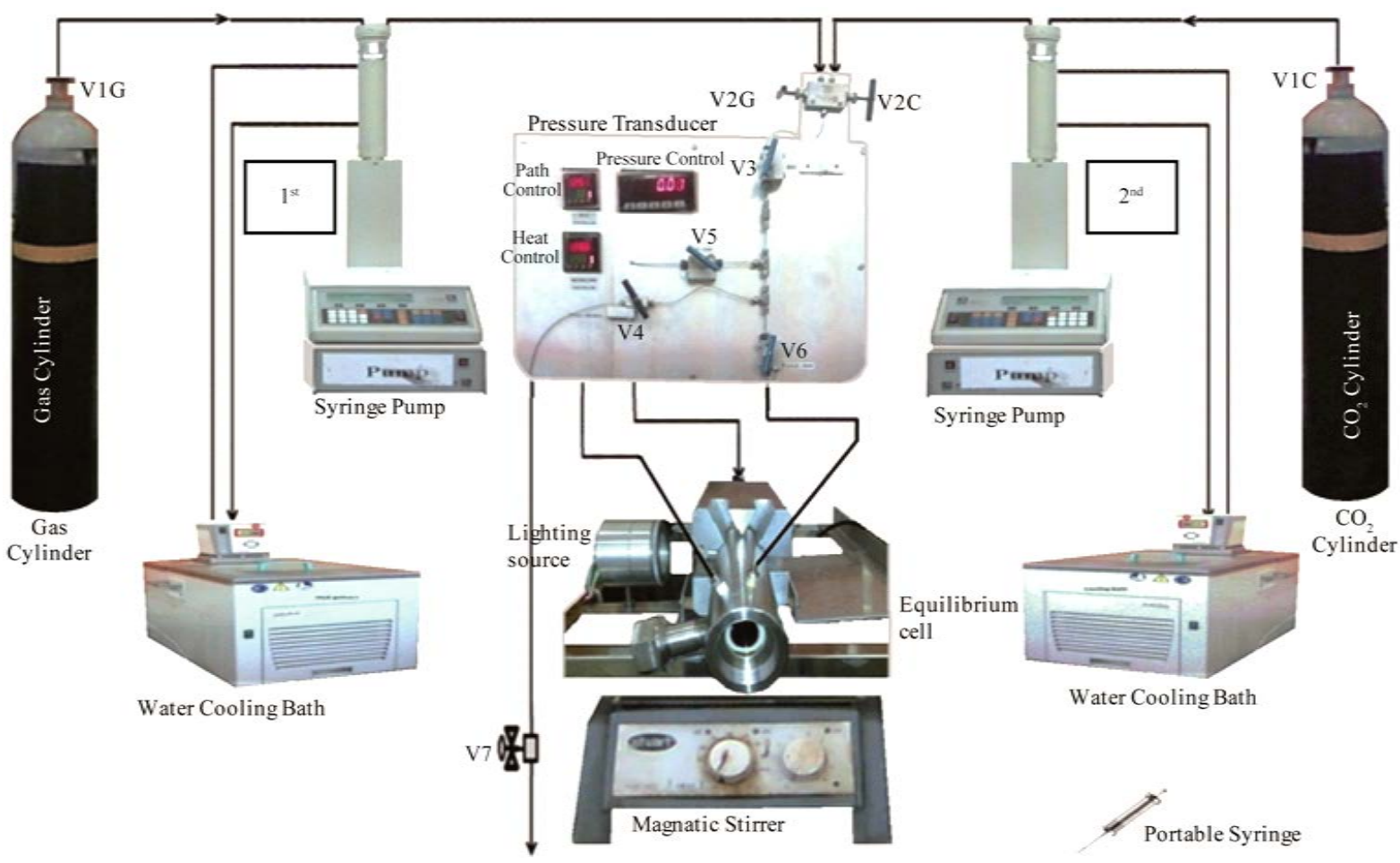

Figure 1. A visual diagram of the static-synthetic method used in this work.

includes a movable piston, which permits the control of pressure inside the cell. Phase transitions are recorded through pressure manipulation using the syringe pump and a solvent $\left(\mathrm{CO}_{2}\right)$ as a pressurizing fluid. The set of valves used in the unit and their objectives are discussed elsewhere [13].

The equilibrium cell consists of a 316 stainless-steel cylinder, with a $17.2 \mathrm{~mm}$ internal diameter and $176 \mathrm{~mm}$ length. The cell is equipped with a piston for system volume and pressure variation. The equilibrium cell is heated by an automatically controlled electric heating system. The equilibrium cell has two top holes for thermocouple connection and feed valve connection or gas removal during the recombination process. The equilibrium cell has also three holes: a rear hole, lateral and front windows respectively for piston displacement, light source and infrared device to detect and record phase transitions (Figure 2). The piston has two O-rings (BUNA N90) that allow smooth slip inside the cell for pressurizing or depressurizing. The O-rings ensure the sealing (insulation) of the sample (Figure 3). 


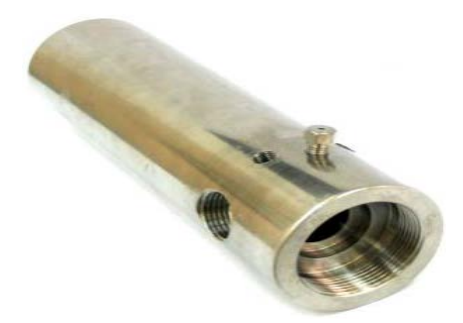

Figure 2. Picture of the equilibrium cell used in this work.
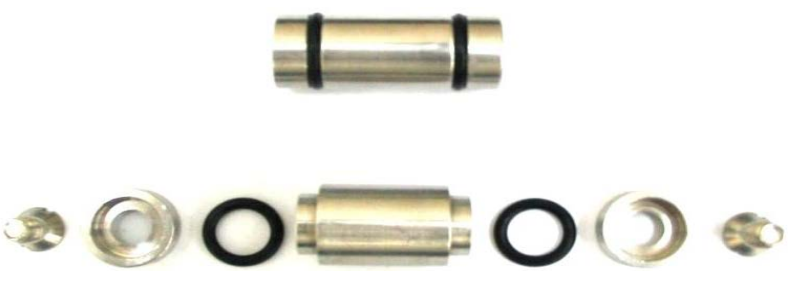

Figure 3. Details of the components of the piston used in the equilibrium cell.

For phase equilibrium measurements through the static-synthetic method, a suitable device for quantifying the amount injected into the equilibrium cell and also for handling the system pressure is required. Syringe-type pumps are ideally designed for this purpose and they have an inner cylinder connected to an automatic flow and a pressure indicator controller (COEL K484P). Each of the two syringe pumps (ISCO Brand, Model 260D) has an inner cylinder of $266 \mathrm{ml}$ and a discharge pressure of up to 500 bar. The chamber cylinders of the pumps are jacketed to keep their temperature constant using water circulating baths.

The equilibrium assembly of the cell begins with the adjustment of the piston O-rings tightness. This step requires special care, because if the piston tightening is weak it will allow fluid passage into the cell and thus changes the overall composition. At the same time piston tightening should not be too strong to avoid pressure drop between the sample and the process line.

The system was continuously stirred and the pressure inside the cell was gradually increased until the condition of a single-phase system was obtained, then the pressure was reduced gradually until the saturation pressure of the system was recorded at the specific reservoir bottom hole temperature. For saturation pressure measurements, the light source from the lateral window of the equilibrium cell was turned on and a digital camera (Genius eFace 1325R) with an infrared device that provides superior image quality under any light conditions; even in the dark. All the measurements in the above tests were performed using the infrared device which allows phase transition detection with $<1$ bar (or $\pm 1 \%$ error).

\section{The Recombination Test Procedure}

Due to the difficulties and costs involved in bottom-hole samples' measurements, it was intended in this work to reproduce the original reservoir fluid with bubble point pressure and composition as close as possible to the original reservoir fluid under test. Thus, the recombination process was performed here to reproduce the reservoir fluid for further PVT studies using gas samples from the first-stage separator and oil samples from stocktank oil (dead oil) with compositions provided by the Commercial Service Provider. The gas from the first-stage separator is a mixture of hydrocarbons up to $\mathrm{C}_{7}^{+}$. The detail of recombination test procedure can be found in [13] and it is summarized by the flow chart shown in Figure 4.

The experimental procedure for the recombination process using this type of experimental setup, begins with loading the gas from the gas cylinder (at ambient temperature) into the chamber of the $1^{\text {st }}$ syringe pump using valve V1G. The temperature in the chamber of syringe pump is kept constant at $283.15 \mathrm{~K}$ using the watercooled circulating system (Julabo F34, Germany). Then valve V1G was closed and the pressure was raised to 100 bar inside the chamber. The stabilization of the system (zero pump flow) requires about 10 to $15 \mathrm{~min}$, and should be carefully done to avoid any trace flow that might lead to systematic error in the measured volume of the injected gas. 


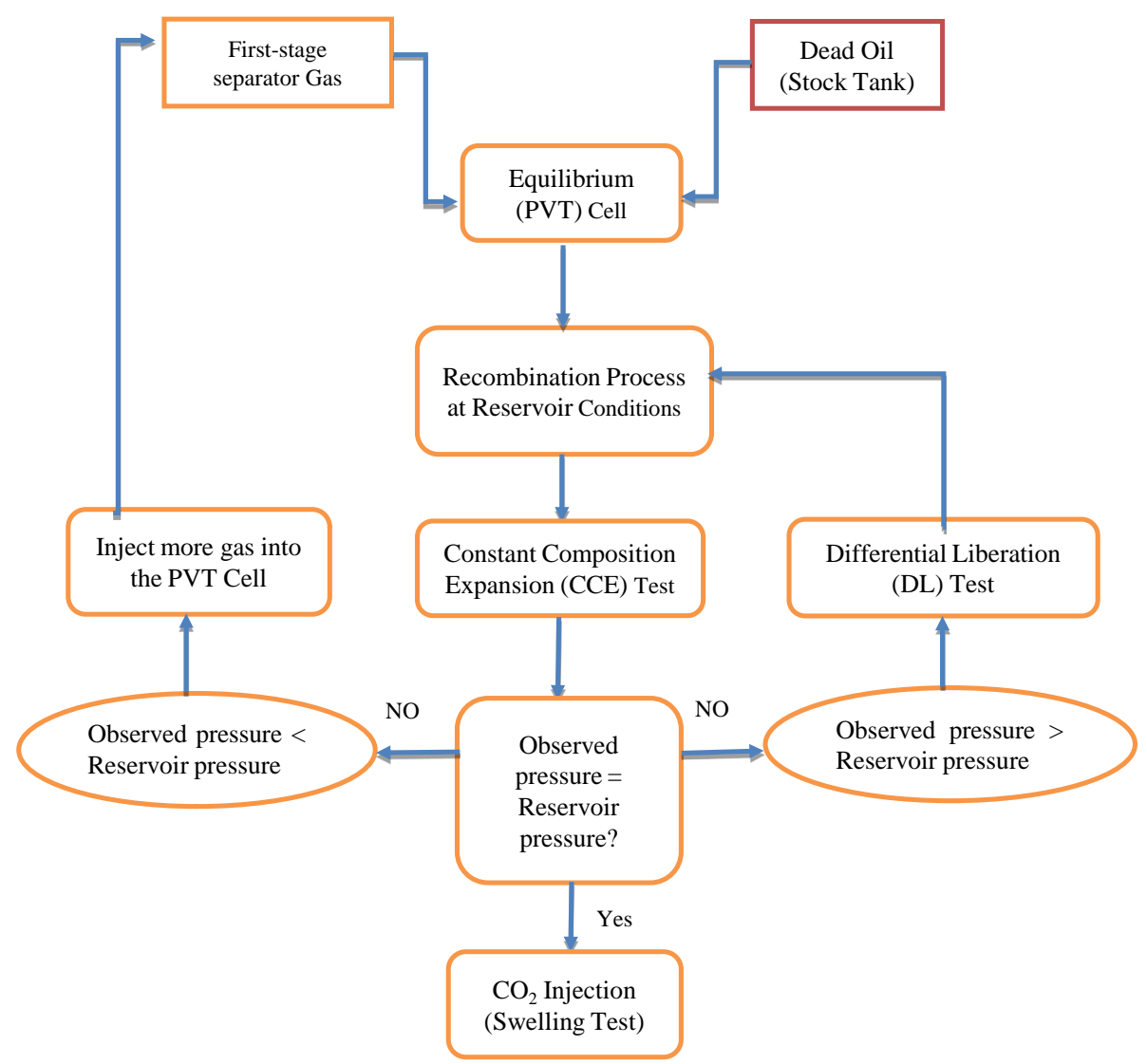

Figure 4. Flow chart for the recombination test procedure.

A typical recombination process starts by insertion of a precise amount of the stock-tank oil into the equilibrium cell through valve V6 using the portable syringe. The cell is then connected to the process lines (feed, pressurizing/depressurizing and thermocouples). Once the system in the $1^{\text {st }}$ syringe pump chamber is stabilized, the volume of the gas inside the chamber is recorded and a pre-calculated volume of that gas is injected into the equilibrium cell through valves V2G, V3 and V6. Then valves V3 and V6 are closed. The starting temperature inside the equilibrium cell is the room temperature. The magnetic stirrer is then switched on and the temperature is raised in steps to the reservoir bottom hole temperature. This process usually takes about 15 minutes. The light source from the lateral window on the equilibrium cell is turned on and any phase transition will be detected and recorded by the infrared web-cam. The pressure is then raised to a pressure well above the bubble point of the reservoir fluid (i.e., 154.9 bar for well A\#22 and 161.7 bar for well \#33) until a monophasic fluid is obtained, while maintaining the reservoir bottom hole temperature $\left(235^{\circ} \mathrm{F}\right.$ for well $\mathrm{A} \# 22$ and $257^{\circ} \mathrm{F}$ for well A\#33). Then the pressure is gradually reduced until the first bubble is observed. If the recorded bubble pressure is away from the reservoir pressure, then follow the procedure depicted in Figure 4. In all cases, the pressure shall be monitored by the pressure indicator controller.

\section{Calculations for the Recombination Process}

Since the gas composition obtained from the gas cylinder is different from that obtained by flashing the reservoir monophasic fluid directly to standard conditions, this kind of recombination process can lead to a live oil a little different from the reservoir fluid, therefore, the vapor-to-oil molar ratio has to be adjusted until a monophasic fluid is obtained with a fluid composition of minimum deviation from that of the reservoir fluid under test. The optimized vapor-to-oil molar ratios have been found 0.5183 for wells A\#22 and 0.5603 for well A\#33, which are almost the same as those given by the Commercial Service Provider. For minimum deviation in the methane concentration between the reservoir and the recombined fluids, the vapor-to-oil molar was found to be around 
0.42 for both wells.

The global composition of component $i$ in the monophasic fluid is obtained through a global material balance:

$$
z_{i}=\beta y_{i}+(1-\beta) x_{i}
$$

where $\beta$ is the vapor-to-oil molar ratio, $x_{i}$ and $y_{i}$ are the mole fractions of component $i$ in the liquid phase and vapor phase, respectively. The values of $\beta, x_{i}$ and $y_{i}$ for wells A\#22 and A\#33 were obtained by flashing the monophasic fluid from the well condition to the standard conditions $\left(60^{\circ} \mathrm{F}\right.$ and $\left.14.7 \mathrm{psia}\right)$. The resulting gas and liquid phases were then analyzed by gas chromatography. For the project chart, the values of $x_{i}$ and $y_{i}$ were obtained by chromatography analysis of the stock-tank oil and the gas from the first-stage separator, respectively.

Since the two-stage recombination process is performed by injecting the gas into the stock-tank oil, for the phase behavior measurement of the live oil, the overall composition of the mixture has to be computed. Since the mass of the dead oil is known, the mass of the gas to be injected has to be estimated in order to obtain the mass of the live oil. For these purposes the same molar ratio of the project was used:

$$
\frac{n^{V}}{n_{t}}=0.42 \text { and } \frac{n^{L}}{n_{t}}=0.58
$$

where $n^{V}$ and $n^{L}$ are the number of moles in the vapor and liquid phases, respectively, and $n_{t}$ is the total number of moles in both phases. Since

$$
n^{L}=\frac{m^{L}}{M^{L}}=\frac{\rho^{L} V^{L}}{M^{L}}
$$

where $\rho^{L}, V^{L}$ and $M^{L}$ are respectively, the density, volume and average molar weight of the stock-tank oil to be injected in the equilibrium cell. Thus,

$$
n_{t}=\frac{n^{L}}{0.42} \text { and } n^{V}=0.58 n_{t}=0.724 \frac{\rho^{L} V^{L}}{M^{L}} .
$$

For non-ideal gas, the vapor volume is calculated as [3]:

$$
V^{V}=n^{V}\left[\frac{Z^{V} R T}{P}\right]
$$

where $Z^{V}$ is the vapor compressibility factor. Substituting Equation (4) into Equation (5) gives

$$
\begin{aligned}
V^{V} & =0.724\left[\frac{\rho^{L} V^{L}}{M^{L}}\right]\left[\frac{Z^{V} R T}{P}\right] \\
& =0.724\left[\frac{m^{L}}{M^{L}}\right]\left[\frac{Z^{V} R T}{P}\right] .
\end{aligned}
$$

In order to calculate $V^{V}$, the compressibility factor of the gas mixture has to be determined using, for example, the theory of corresponding state which requires the reduced temperature, $T_{r m}$, and reduced pressure, $P_{r m}$, of the gas mixture; which requires the estimation of the mixture critical temperature, $T_{c m}$, and critical pressure, $P_{c m}$, for example, using the Kay's rule (Equation (7)) and the composition and the critical properties of the pure components of the gas mixture presented in Table A1 in the Appendix.

$$
T_{c m}=\sum_{i=1}^{n} y_{i} T_{c i} \text { and } P_{c m}=\sum_{i=1}^{n} y_{i} P_{c i} .
$$

The $Z$ factor was estimated by the Brill and Beggs correlation [14]:

$$
Z=A+(1-A) \mathrm{e}^{-B}+C P_{p r}^{D}
$$

where $P_{p r}$ and $T_{p r}$ are the pseudo-reduced pressure and temperature, respectively. The other parameters used in Equation (8) are as follows: 


$$
\begin{aligned}
& A=1.39\left(T_{p r}-0.92\right)^{0.5}-0.36 T_{p r}-0.101 \\
& B=P_{p r}\left(0.62-0.23 T_{p r}\right)+P_{p r}^{2}\left(\frac{0.066}{\left(T_{p r}-0.86\right)}-0.037\right)+0.32 P_{p r}^{6} \cdot \mathrm{e}^{\left[-20.723\left(T_{p r}-1\right)\right]} \\
& C=0.132-0.32 * \log T_{p r} \\
& D=\mathrm{e}^{\left(0.715-1.128 T_{p r}+0.42 T_{p r}^{2}\right)} .
\end{aligned}
$$

The above correlation (Equation (8)) has been found adequate ( $\pm 2 \%$ error) for a temperature range of $80^{\circ} \mathrm{F}$ $340^{\circ} \mathrm{F}$ and pressures $<10,000$ psia [7]. The main advantage of this correlation is being explicit in $Z$.

In this work, the gas is injected from the $1^{\text {st }}$ syringe pump at $283.15 \mathrm{~K}$ and 100 bar which correspond to the $T_{r m}$ and $P_{r m}$ values shown in Table 3 for wells A\#22 and A\#33. Assuming the gas used to be a natural gas [15], then after estimating the $Z$-factor in terms of the mixture pseudo-reduced properties, Equation (6) can be used to estimate $V^{V}$; the volume of the gas to be injected into the equilibrium cell. Further details on the recombination results are presented later.

\section{The Swelling Test Procedure}

The swelling test experimental procedure is as follows:

1) Follow all the steps of the recombination process until you obtain almost the same reservoir bubble point pressure at the reservoir bottom hole temperature $\left(235^{\circ} \mathrm{F}\right.$ for well A\#22 or $257^{\circ} \mathrm{F}$ for well A\#33). The corresponding bubble point pressures should be 154.9 bar for well A\#22 and 161.7 bar for well A\#33. Wait for the $2^{\text {nd }}$ syringe pump to stabilize, then record the initial volume of the gas inside its chamber, $V_{i}$.

2) Decrease the equilibrium cell pressure gradually starting from the saturation pressure to a lower pressure, say, 60 bar, by pulling the equilibrium cell piston back using the $2^{\text {nd }}$ syringe pump mechanism. In this case, a two-phase system is obtained.

3) Close the pressurizing/depressurizing valve, V5, and raise the pressure in the $2^{\text {nd }}$ syringe pump chamber back to saturation pressure and wait until the pump stabilizes, then open valve V5 directly to pressurize the equilibrium cell back to saturation pressure. In this case, a monophasic fluid is obtained.

4) Let the $2^{\text {nd }}$ syringe pump to stabilize and then record the final volume of the gas in its chamber, $V_{f}$. Then the volume of the recombined (live) oil, $V^{0}$, in the equilibrium cell is equal to the displaced volume in the $2^{\text {nd }}$ syringe pump chamber, i.e., $V^{0}=V_{\text {disp live oil }}=V_{i}-V_{f}$.

Table 3. Sample result for the volume of the gas to be transferred from the $1^{\text {st }}$ syringe pump chamber to the equilibrium cell for wells A\#22 and A\#33.

\begin{tabular}{ccc}
\hline Property & Well A\#22 & Well A\#33 \\
\hline Vapor-to-oil molar ratio, $\beta$ & 0.4199 & 0.4196 \\
$P$, bar (in $1^{\text {st }}$ syringe pump chamber) & 100 & 100 \\
$T, \mathrm{~K}$ (in $1^{\text {st }}$ syringe pump chamber) & 283.15 & 283.15 \\
$P_{c m}$, bar (stock-tank oil) & 46.324 & 46.862 \\
$T_{c m}, \mathrm{~K}$ (stock-tank oil) & 231.66 & 223.25 \\
$P_{r m}$ (stock-tank oil) & 2.159 & 2.1339 \\
$T_{r m}$ (stock-tank oil) & 1.222 & 1.2683 \\
$Z^{V}$ (Using Equation (8)) & 0.5804 & 0.5712 \\
$\rho^{L}$, g/ml (Field data) & 0.825 & 0.816 \\
$M^{L}$, g/g-mol (Field data) & 200.04 & 190.74 \\
$m^{L}, \mathrm{~g}(\mathrm{mass}$ of injected stock-tank oil) & 5.70 & 5.70 \\
$V^{V}$, ml/g (using Equation (6)) & 0.364 & 0.375 \\
\hline
\end{tabular}


5) Decrease the pressure in the equilibrium cell gradually to 60 bar. Then close V5 and raise the pressure inside the $2^{\text {nd }}$ syringe pump chamber to 240 bar. This pressure is used for $\mathrm{CO}_{2}$ injection at the corresponding reservoir bottom hole temperature.

6) Let the $2^{\text {nd }}$ syringe pump to stabilize and record the volume of the $\mathrm{CO}_{2}$ inside its chamber, $V_{\text {before injecting } \mathrm{CO}_{2}}$. Then open valves $\mathrm{V} 2 \mathrm{C}, \mathrm{V} 3$ and $\mathrm{V} 6$ and inject the pre-calculated volume of $\mathrm{CO}_{2}, V_{\mathrm{CO}_{2} \text { injected }}$ (for each $\mathrm{CO}_{2}$ mass fraction) into the equilibrium cell. The volume of the remaining $\mathrm{CO}_{2}$ inside the $2^{\text {nd }}$ syringe pump chamber,

$$
V_{\text {after injecting } \mathrm{CO}_{2}}=V_{\text {before injecting } \mathrm{CO}_{2}}-V_{\mathrm{CO}_{2} \text { injected }} \text {. }
$$

7) Close valve V6 and gradually decrease the pressure inside the $2^{\text {nd }}$ syringe pump chamber from 240 bar to 60 bar.

8) Open valve V5 and gradually increase the pressure inside the equilibrium cell until a monophasic fluid is observed and then gradually decrease the pressure until the first phase separation is observed. Record the observed phase transition pressure ( $P_{\text {bub }}$ or $\left.P_{\text {dew }}\right)$.

9) Let the $2^{\text {nd }}$ syringe pump to stabilize and then record the initial volume of the $\mathrm{CO}_{2}$ in its chamber, $V_{i, \mathrm{CO}_{2}}$.

10) Gradually reduce the equilibrium cell pressure from the observed phase transition pressure down to 60 bar in order to leave the piston at its maximum position at the backside of the equilibrium cell.

11) Close valve V5 and increase the pressure inside the $2^{\text {nd }}$ syringe pump back to the observed phase transition pressure. Re-open valve $\mathrm{V} 5$ to pressurize the equilibrium cell and let the syringe pump to stabilize again and then record the final volume of the $\mathrm{CO}_{2}$ in its chamber, $V_{f, \mathrm{CO}_{2}}$. Thus the displaced volume of the $\mathrm{CO}_{2} /$ live oil system, $V^{01}=V_{\text {disp } \mathrm{CO}_{2} / \text { live oil }}=V_{i, \mathrm{CO}_{2}}-V_{f, \mathrm{CO}_{2}}$.

12) The swelling factor defined as the ratio between the volume of the saturated $\mathrm{CO}_{2} /$ live oil mixture and the volume of the saturated live oil at the reservoir temperature [16] is then calculated as

$$
V^{\text {sw }}=\frac{V_{\text {disp } \mathrm{CO}_{2} / \text { live oil }}}{V_{\text {displive oil }}}=\frac{V^{01}}{V^{0}} .
$$

It should be mentioned that the $\mathrm{CO}_{2}$ chart [16] was used to determine the density of $\mathrm{CO}_{2}$ at the given temperature and pressure in order to calculate the displaced $\mathrm{CO}_{2}$ mass in the $2^{\text {nd }}$ syringe pump chamber, which has to be placed in the equilibrium cell. The swelling tests results for various $\mathrm{CO}_{2}$ mass fractions are presented later.

\section{Thermodynamic Modeling and Simulation}

In designing gas injection schemes and in many reservoir engineering situations, reliable methods are necessary to predict the gas-saturated crude oil density which is required for the calculation of the oil swelling and the oil formation volume factors. This has led to many prediction methods and correlations which are generally applicable to specific cases and often require knowledge of molar volume and solubility of the gas in the live oil at the reservoir conditions. These correlations are empirical by their nature and thus can lead to large errors when extrapolated beyond the range of variables covered in their study [17].

Equations of state are used for generating the fluid model that can help in predicting the reservoir fluid properties at different pressures/temperatures and compositions and also help in material balance and flash calculations. The use of an equation of state at certain temperature and pressure with known overall composition, allows determining whether the fluid exists as a single or a multi-phase system and to estimate the density and composition of the existing phase(s) [18].

For PVT data correlations, the Peng-Robinson equation of state (PR EOS) represents a significant improvement over the Soave-Redlich-Kwong equation of state (SRK EOS); while the SRK EOS predicts a critical compressibility factor, $Z_{c, S R K}=0.333$, the corresponding value predicted by PR EOS, $Z_{c, P R}=0.307$ which is closer to the reported experimental compressibility factors for hydrocarbons which are usually between 0.2 and 0.29 . The PR EOS [19] is given by

where

$$
P=\frac{R T}{v-b}-\frac{a}{v(v+b)+b(v-b)}
$$

$$
b=0.07780 \frac{R T_{c}}{P_{c}}
$$




$$
a_{c}=\left(\frac{0.45724 R^{2} T_{c}^{2}}{P_{c}}\right) .
$$

For components with acentric factor $\omega \leq 0.49$, the following function is used:

$$
m=0.379642+1.5422 \omega-0.2699 \omega^{2}
$$

and for components with acentric factor $\omega>0.49$, the following function is used:

$$
m=0.379642+1.48502 \omega-0.164423 \omega^{2}-0.016666 \omega^{3} .
$$

A third parameter, usually known as the volume-shift parameter $\left(c_{i}\right)$ can be introduced through the following relation [20]:

$$
v^{(3)}=v^{(2)}-\sum_{i=1}^{N} z_{i} c_{i}
$$

where $v^{(2)}$ is the mixture volume predicted by the two-parameter equation of state, $v^{(3)}$ is the mixture corrected volume, and $z_{i}$ is the liquid or vapor mole fraction $\left(x_{i}\right.$ or $\left.y_{i}\right)$ of component $i$. The shift in volume leads to a convenient reduction in the $Z$ factor. The values of $c_{i}$ are commonly calculated by comparing the observed liquid molar volume at standard condition $\left(v_{i}^{\text {OBS }}\right)$ with that obtained by the two-parameter EOS at the same conditions $\left(v_{i}^{E O S}\right)$. This difference determines the value of $c_{i}$ for component $i$.

$$
c_{i}=v_{i}^{E O S}\left(P_{s t}, T_{s t}\right)-v_{i}^{O B S}\left(P_{s t}, T_{s t}\right)
$$

The dimensionless volume-shift parameter $\left(s_{i}\right)$ is usually defined as a ratio between $c_{i}$ and $b_{i}$ (pure-component co-volume defined by Equation (11)).

$$
s_{i}=\frac{c_{i}}{b_{i}} .
$$

The calculated shift parameters for the reservoir fluid of well A\#33 are listed in Table A2 in the Appendix. It should be noted that the volume-shift correction has no effect on the iso-fugacity condition and thus, it does not affect other predicted equilibrium properties like saturation pressure and the $k$ values [18].

For fluid mixtures, the van der Waals mixing rules are commonly used

$$
\begin{gathered}
a=\sum_{i=1}^{n} \sum_{i=1}^{n} x_{i} x_{j} a_{i j} \\
a_{i j}=\left[\left(a_{i} a_{j}\right)^{0.5}\right]\left(1-k_{i j}\right) \\
b=\sum_{i=1}^{n} x_{i} b_{i}
\end{gathered}
$$

where $k_{i j}$ 's, usually referred to as binary interaction parameters, are calculated by parameterizing the EOS with experimental $k$ values [21]. For hydrocarbon systems, the $k_{i j}$ 's are commonly set to zero, except for describing interaction between hydrocarbons and non-hydrocarbons and between light and heavy hydrocarbons. An alternative method proposed by Chueh and Prausnitz [22] can also be used for evaluating $k_{i j}$ 's:

$$
k_{i j}=A\left\{1-8 \frac{\left(v_{c i} v_{c j}\right)^{1 / 2}}{\left(v_{c i}^{1 / 2}+v_{c j}^{1 / 2}\right)^{3}}\right\}
$$

where $v_{c i}$ is the critical molar volume of component $i$. The coefficient $A$ is usually adjusted to match the measured saturation pressures of the mixture.

Since correlations for critical pressure are in general less accurate than correlations for critical temperature, the critical pressure of the $\mathrm{C}_{20}^{+}$fraction together with the binary interaction parameter of $\mathrm{C}_{20}^{+}$was used as regression variables to fit experimental pressure saturation data with the modified PR EOS, which is built in the PVTi (version 2010.1) and the PVTpro (version 5.1) simulators of the Schlumberger software is used in this work.

The PVTi simulator was used in this work to reproduce the live oil (by combining the first-stage separator gas and the stock-tank oil) and also to predict the recombined oil characteristics at the reservoir saturation pressure 
and bottom hole temperature. The PVTpro simulator was used to investigate the oil swelling rate and establish the relationship between saturation pressure and the injected $\mathrm{CO}_{2}$ mass fraction. The results of simulation are presented later.

\section{Results and Discussion}

\subsection{Experimental Results}

The recombination process was first performed to obtain the same saturation pressure at which the reservoir fluid was sampled $\left(P^{\text {sat0 }}\right)$ and the corresponding volume of the live oil, $V^{0}$, which were determined by stabilizing the $2^{\text {nd }}$ syringe pump. More than 10 experimental runs were done for each well at the specific reservoir bottom hole temperature $\left(235^{\circ} \mathrm{F}\right.$ for well $\mathrm{A} \# 22$ and $257^{\circ} \mathrm{F}$ for well A\#33). Table 4 and Table 5 show the recombination tests results. The resulting live oils have been used in this work as the starting fluids for the subsequent swilling tests.

The static-synthetic method, which consists of preparing a mixture of known overall composition, was used to observe the fluid phase behavior by changing the pressure of the equilibrium cell at the specific reservoir bottom hole temperature. Typical results of the static-synthetic methods are bubble point and dew point curves. Phase changes are determined visually by pressure adjustments at constant temperature. It is important to emphasize

Table 4. Recombination results and live oil volume, $V^{0}$, for well $\mathrm{A} \# 22$ at 2277 psia and $235^{\circ} \mathrm{F}$.

\begin{tabular}{cccccccc}
\hline Run & $m_{\text {dead oil }}(\mathrm{g})$ & $V_{\text {dead oil }}(\mathrm{ml})$ & $V_{\text {gas }}(\mathrm{ml})$ & $m_{\text {gas }}(\mathrm{g})$ & $m_{\text {live oil }}(\mathrm{g})$ & $V^{0}(\mathrm{ml})$ & $P^{\text {sat0 }}(\mathrm{bar})$ \\
\hline 1 & 6.14 & 7.442 & 0.392 & 0.484 & 6.624 & 6.31 & 157.3 \\
2 & 6.19 & 7.503 & 0.395 & 0.488 & 6.678 & 6.97 & 157.8 \\
3 & 6.15 & 7.455 & 0.392 & 0.485 & 6.635 & 7.91 & 157.4 \\
4 & 6.22 & 7.539 & 0.397 & 0.491 & 6.711 & 6.60 & 158.0 \\
5 & 6.20 & 7.515 & 0.395 & 0.489 & 6.689 & 7.13 & 157.9 \\
6 & 5.70 & 6.909 & 0.364 & 0.450 & 6.150 & 6.73 & 157.2 \\
7 & 5.84 & 7.079 & 0.372 & 0.461 & 6.301 & 7.74 & 156.9 \\
8 & 6.18 & 7.491 & 0.394 & 0.488 & 6.668 & 7.32 & 157.6 \\
9 & 5.95 & 7.212 & 0.379 & 0.469 & 6.419 & 7.58 & 157.1 \\
10 & 6.17 & 7.479 & 0.394 & 0.487 & 6.657 & - & 157.5 \\
\hline
\end{tabular}

Table 5. Recombination results and live oil volume, $V^{0}$, for well A\#33 at 2377 psia and $257^{\circ} \mathrm{F}$.

\begin{tabular}{|c|c|c|c|c|c|c|c|}
\hline Run & $m_{\text {dead oil }}(\mathrm{g})$ & $V_{\text {dead oil }}(\mathrm{ml})$ & $V_{\text {gas }}(\mathrm{ml})$ & $m_{\text {gas }}(\mathrm{g})$ & $m_{\text {live oil }}(\mathrm{g})$ & $V^{0}(\mathrm{ml})$ & $P^{\text {sat0 }}$ (bar) \\
\hline 1 & 5.94 & 7.279 & 0.391 & 0.492 & 6.432 & 7.36 & 165.2 \\
\hline 2 & 5.68 & 6.961 & 0.374 & 0.470 & 6.150 & 8.40 & 164.7 \\
\hline 3 & 5.61 & 6.875 & 0.370 & 0.464 & 6.074 & 9.44 & 164.5 \\
\hline 4 & 5.46 & 6.691 & 0.360 & 0.452 & 5.912 & 8.30 & 163.8 \\
\hline 5 & 5.63 & 6.900 & 0.371 & 0.466 & 6.096 & 8.56 & 164.6 \\
\hline 6 & 5.48 & 6.716 & 0.361 & 0.453 & 5.933 & 8.14 & 163.9 \\
\hline 7 & 5.70 & 6.985 & 0.375 & 0.472 & 6.172 & 9.20 & 164.2 \\
\hline 8 & 5.39 & 6.605 & 0.355 & 0.446 & 5.836 & 9.22 & 163.4 \\
\hline 9 & 5.90 & 7.230 & 0.389 & 0.488 & 6.388 & 8.70 & 165.0 \\
\hline 10 & 5.58 & 6.838 & 0.368 & 0.462 & 6.042 & - & 164.1 \\
\hline
\end{tabular}


that for a system with known global composition at a given temperature and pressure, the static-synthetic technique can only determine whether the system is composed of one, two or three phases. The respective phase compositions are still unknown as shown in the photographic image for the single phase (dead oil) system for well A\#33 (Figure 5). On the other hand, Figure 6 shows the photographic image for initial phase formation in the live oil system for well A\#33.

In the swelling tests, the $\mathrm{CO}_{2}$ was then injected into the live oil (recombined oil) to observe a two-phase system $P_{(\mathrm{LV})}^{\mathrm{sat}}$, and sometimes in a narrow range, a three-phase system $P_{(\mathrm{LLV})}^{\mathrm{sat}}$, depending on the pressure and the mass fraction of $\mathrm{CO}_{2}$ in the $\mathrm{CO}_{2} /$ live oil system. It is worth mentioning that the three-phase observed here was not confirmed by the Commercial Service Provider.

The saturation pressure, $P^{\text {sat }}$, and the final volume of the $\mathrm{CO}_{2} /$ live oil system $V^{01}$, were noted after stabilizing the $2^{\text {nd }}$ syringe pump. The relative swelling volume $\left(V^{s w}\right)$ was then calculated as $V^{s w}=V^{01} / V^{0}$. Table 6 and Table 7 present the experimentally observed and the calculated swelling test results for wells A\#22 and A\#33, respectively. It is clear that substantial increases in the saturation pressure and the swelling factor are obtained as result of the increase in the $\mathrm{CO}_{2}$ mass fraction in the $\mathrm{CO}_{2} /$ live oil system. For example, the swelling factor has increased from 1.0 to about 1.7 upon the increase of the $\mathrm{CO}_{2}$ mass fraction from 0.0 to 0.6 . In general, the higher the swelling factor the better the enhanced oil recovery. On the other hand, Figure 7 shows the swelling factor

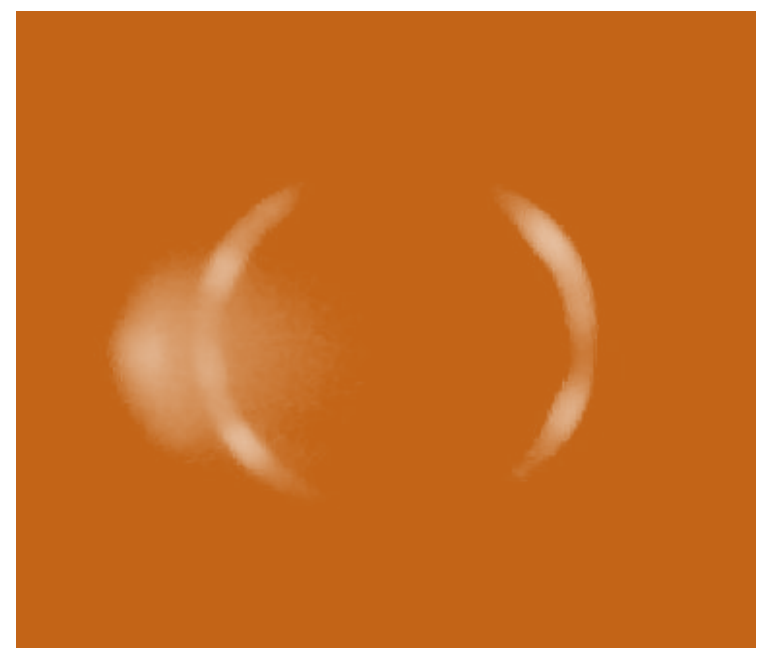

Figure 5. Monophasic fluid for well A\#33 at $257^{\circ} \mathrm{F}$.

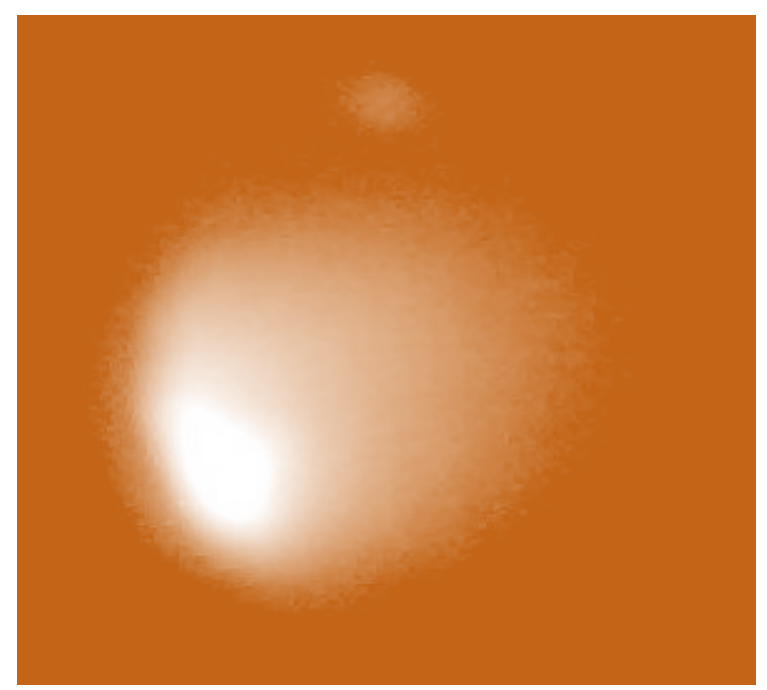

Figure 6. Initial bubble formation in the live oil of well $\mathrm{A} \# 33$ at $257^{\circ} \mathrm{F}$. 
Table 6. Swelling test results for the $\mathrm{CO}_{2}$ /live oil system for well A\#22 at 2277 psia and $235^{\circ} \mathrm{F}$.

\begin{tabular}{|c|c|c|c|c|c|c|c|c|}
\hline \multirow{2}{*}{ Run } & \multicolumn{2}{|c|}{ From recombination results } & \multicolumn{6}{|c|}{ Swelling results } \\
\hline & $P^{\text {sat0 }}$ (bar) & $V^{0}(\mathrm{ml})$ & $w_{\mathrm{CO}_{2}}$ & $V_{\mathrm{CO}_{2}}(\mathrm{ml})$ & $P_{(\mathrm{LV})}^{\text {sat }} \quad$ (bar) & $P_{(\mathrm{LLV})}^{\mathrm{sat}} \quad$ (bar) & $V^{01}(\mathrm{ml})$ & $V^{\mathrm{sw}}=V^{01} / V^{0}$ \\
\hline 1 & 157.3 & 6.31 & 0.05 & 1.117 & 167.2 & - & 6.43 & 1.02 \\
\hline 2 & 157.8 & 6.97 & 0.10 & 2.363 & 192.6 & - & 7.90 & 1.13 \\
\hline 3 & 157.4 & 7.91 & 0.15 & 3.741 & 205.9 & - & 9.03 & 1.14 \\
\hline 4 & 158.0 & 6.60 & 0.20 & 5.343 & 230.4 & - & 8.30 & 1.26 \\
\hline 5 & 157.9 & 7.13 & 0.25 & 7.101 & 242.6 & - & 9.29 & 1.30 \\
\hline 6 & 157.2 & 6.73 & 0.30 & 8.447 & 253.4 & 255.9 & 9.61 & 1.43 \\
\hline 7 & 156.9 & 7.74 & 0.35 & 10.909 & 267.0 & 270.9 & 11.50 & 1.49 \\
\hline 8 & 157.6 & 7.32 & 0.40 & 14.201 & 287.3 & 292.0 & 12.30 & 1.68 \\
\hline 9 & 157.1 & 7.58 & 0.50 & 20.575 & 317.1 & 323.3 & 13.10 & 1.73 \\
\hline 10 & 157.5 & - & 0.60 & 31.902 & 357.4 & - & - & - \\
\hline
\end{tabular}

Table 7. Swelling test results for the $\mathrm{CO}_{2}$ /live oil system for well $\mathrm{A} \# 33$ at 2377 psia and $257^{\circ} \mathrm{F}$.

\begin{tabular}{|c|c|c|c|c|c|c|c|c|}
\hline \multirow{2}{*}{ Run } & \multicolumn{2}{|c|}{ From recombination results } & \multicolumn{6}{|c|}{ Swelling results } \\
\hline & $P^{\mathrm{sat} 0}$ (bar) & $V^{0}(\mathrm{ml})$ & $w_{\mathrm{CO}_{2}}$ & $V_{\mathrm{CO}_{2}}(\mathrm{ml})$ & $P_{(\mathrm{LV})}^{\mathrm{sat}} \quad$ (bar) & $P_{(\mathrm{LLV})}^{\mathrm{sat}} \quad$ (bar) & $V^{01}(\mathrm{ml})$ & $V^{\mathrm{sw}}=V^{01} / V^{0}$ \\
\hline 1 & 165.2 & 7.36 & 0.05 & 1.117 & 178.0 & - & 7.43 & 1.01 \\
\hline 2 & 164.7 & 8.40 & 0.10 & 2.263 & 195.5 & - & 8.82 & 1.05 \\
\hline 3 & 164.5 & 9.44 & 0.15 & 3.549 & 212.0 & - & 10.86 & 1.15 \\
\hline 4 & 163.8 & 8.30 & 0.20 & 4.926 & 235.2 & - & 10.04 & 1.21 \\
\hline 5 & 164.6 & 8.56 & 0.25 & 6.728 & 248.3 & - & 10.79 & 1.26 \\
\hline 6 & 163.9 & 8.14 & 0.30 & 8.448 & 261.1 & 265.1 & 11.07 & 1.36 \\
\hline 7 & 164.2 & 9.20 & 0.35 & 11.041 & 277.3 & 280.5 & 12.97 & 1.41 \\
\hline 8 & 163.4 & 9.22 & 0.40 & 13.012 & 289.1 & 293.2 & 14.48 & 1.57 \\
\hline 9 & 165.0 & 8.70 & 0.50 & 21.083 & 324.0 & 330.0 & 15.14 & 1.74 \\
\hline 10 & 164.1 & - & 0.60 & 30.108 & 400.0 & - & - & - \\
\hline
\end{tabular}

of the $\mathrm{CO}_{2}$ /live oil system as function of saturation pressure for wells $\mathrm{A \# 22}$ (at $235^{\circ} \mathrm{F}$ ) and $\mathrm{A \# 3}\left(\mathrm{at} 257^{\circ} \mathrm{F}\right.$ ). The best fit of the swelling factor vs. saturation pressure is also shown on Figure 7.

Figure 8 and Figure 9 show respectively the photographic images for a monophasic fluid system and a phase transition for the $\mathrm{CO}_{2} /$ live oil system at a $\mathrm{CO}_{2}$ mass fraction of 0.5 for well $\mathrm{A \# 33}$. As can be noted from these images, the phase transition detection device used was very suitable. It is important to highlight that this direct measurement of the saturation pressure without any additional treatment of images is among the very few times reported in literature (e.g. [8]).

Figure 10 and Figure 11 show the effect of the injected $\mathrm{CO}_{2}$ mass fraction on the saturation pressure and phase transformation for wells $\mathrm{A} \# 22$ and A\#33, respectively, at the corresponding reservoir bottom hole temperatures. At $w_{\mathrm{CO}_{2}}<0.3$, the interaction between the hydrocarbon molecules is not affected enough by the presence of $\mathrm{CO}_{2}$ and only conventional vapor-liquid transition is observed while a three-phase (vapor-liquidliquid) system exists at $w_{\mathrm{CO}_{2}} \geq 0.30$. However, the phase transformations can be explained as follows taking well \#33 reservoir fluid as an example. The phase behavior of binary mixtures of $\mathrm{CO}_{2}$ and live oil depends on 


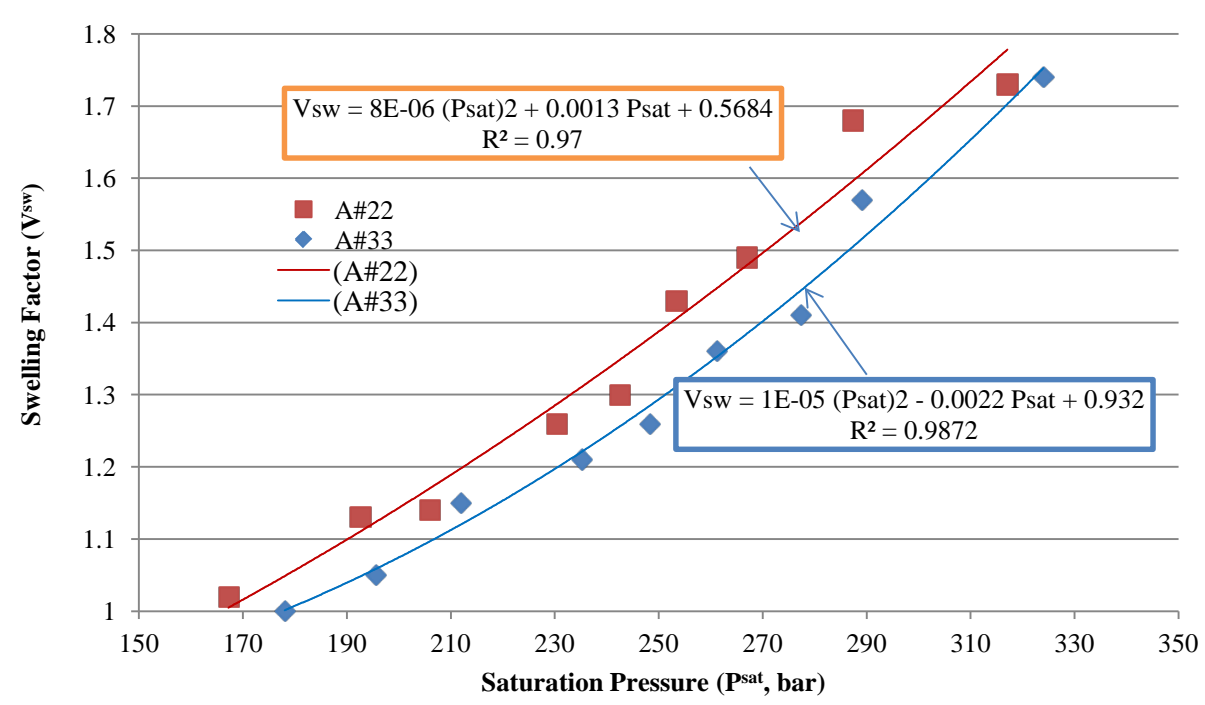

Figure 7. Swelling factor of the $\mathrm{CO}_{2}$ /live oil system as function of saturation pressure for well A\#22 (at $235^{\circ} \mathrm{F}$ ) and well A\#33 (at $257^{\circ} \mathrm{F}$ ).

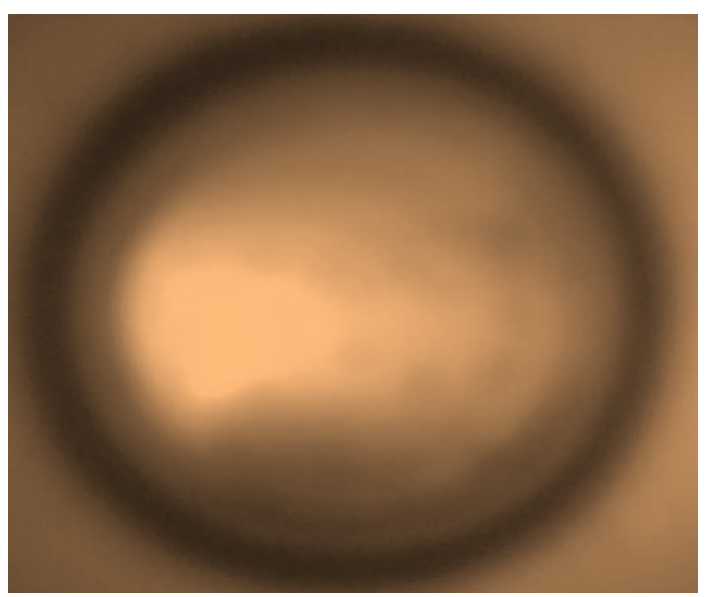

Figure 8. Monophasic fluid of the system $\mathrm{CO}_{2} /$ live oil for well $\mathrm{A} \# 33$ at $257^{\circ} \mathrm{F}$.

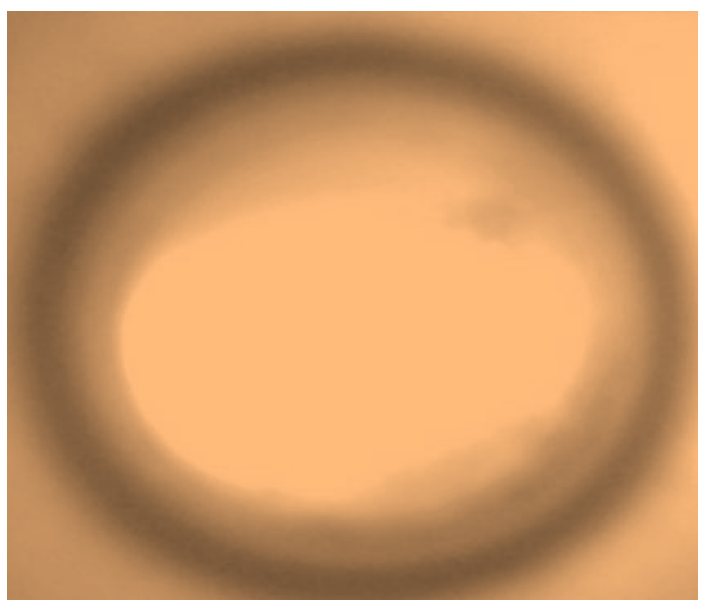

Figure 9. Phase transition in the $\mathrm{CO}_{2} /$ live oil system for well $\mathrm{A} \# 33$ at $257^{\circ} \mathrm{F}$. 


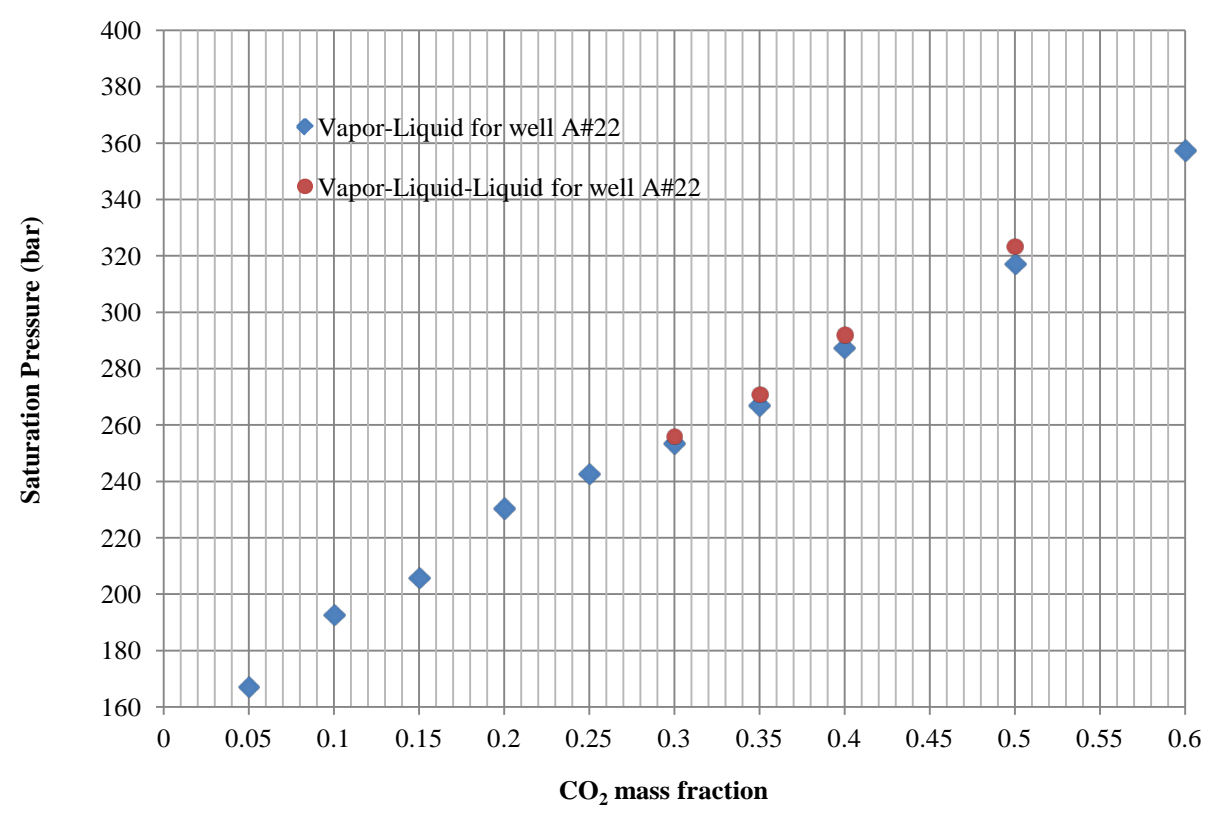

Figure 10. Measured saturation pressure vs. $\mathrm{CO}_{2}$ mass fraction for well A\#22 (235 $\left.{ }^{\circ} \mathrm{F}\right)$.

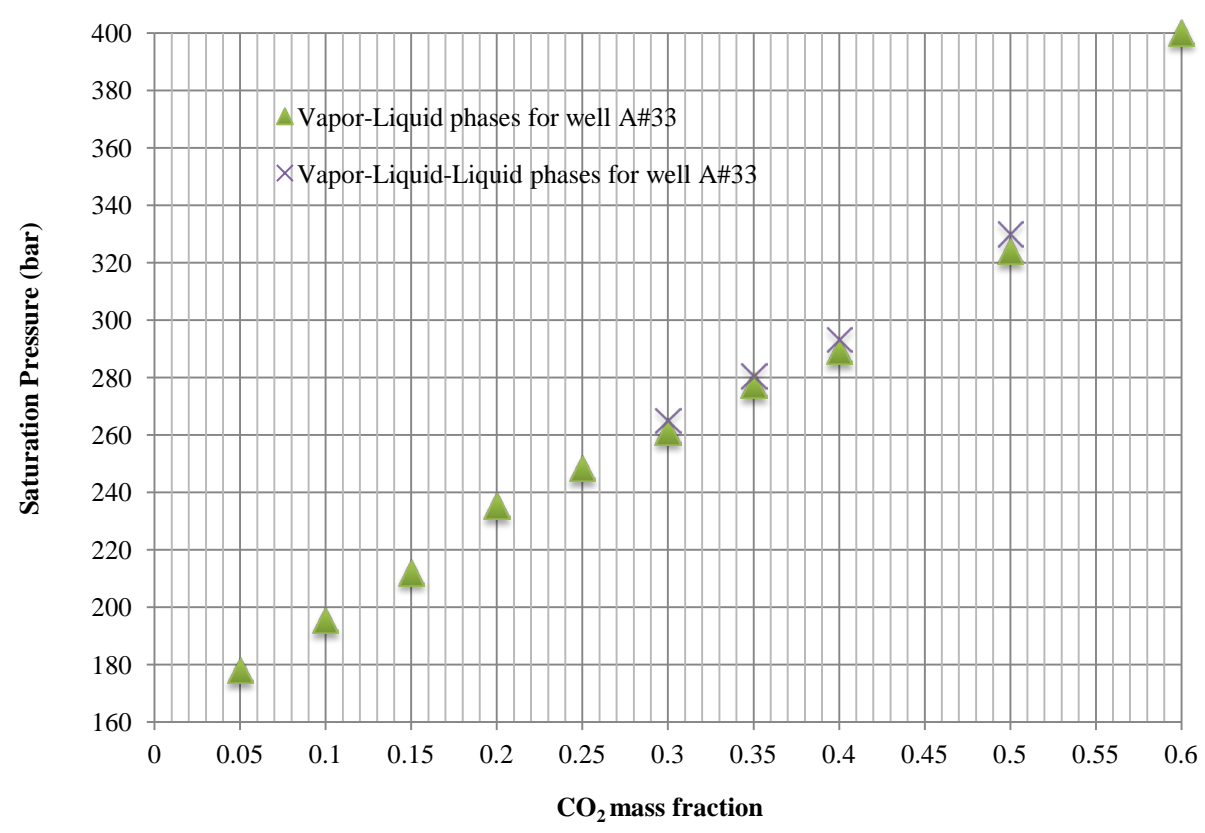

Figure 11. Measured saturation pressure vs. $\mathrm{CO}_{2}$ mass fraction for well A\#33 (257 $\left.{ }^{\circ} \mathrm{F}\right)$.

the $\mathrm{CO}_{2}$ mass fraction and the system pressure. For instance, the original live oil (i.e., $w_{\mathrm{CO}_{2}}=0$ ) is liquid at $P>$ 164.5 bar, but it transforms into two (liquid + vapor) phases at $P<164.5$ bar. For $0<w_{\mathrm{CO}_{2}}<0.3$ a single liquid phase exists at $P \geq 250$ bar while a two phase (liquid + vapor) system forms at $P<199$ bar. At $0.5>w_{\mathrm{CO}_{2}}>0.3$, the phase behavior is more complicated. For instance, at $w_{\mathrm{CO}_{2}}=0.3$, a single liquid phase exists at $P \geq 400 \mathrm{bar}$, a two phase (liquid + vapor) system exists at $P=261.1$ bar and as the pressure is slightly increased $(P=265.1$ bar), the vapor phase, which consists of $\mathrm{CO}_{2}$ and light hydrocarbons, condenses into a second liquid phase, i.e., a (liquid + liquid + vapor) exists. It should be mentioned, as it appears in Figure 10 and Figure 11, that there is a narrow pressure range over which two liquid phases $\left(\mathrm{CO}_{2}\right.$-rich liquid + an oil-rich liquid) and a vapor phase coexist.

The real observation of the three-phase system is shown in Figure 12 for well $\mathrm{A \# 3}$ where the $\mathrm{CO}_{2} /$ live oil 


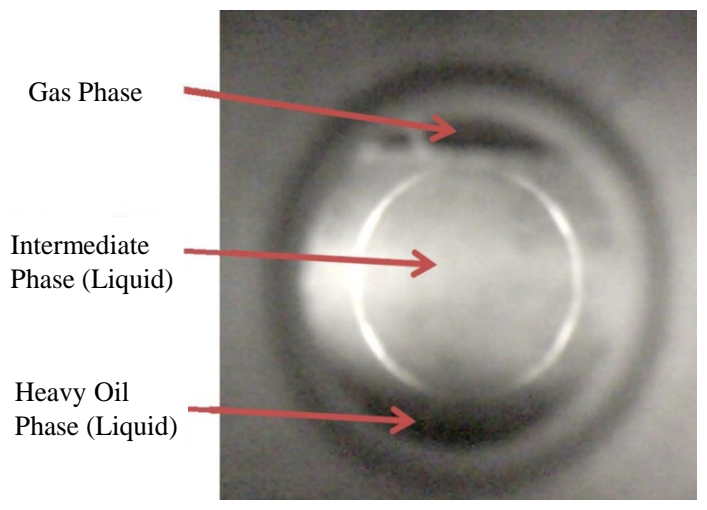

Figure 12. Example of an experimentally observed vapor-liquid-liquid transition for well A\#33 $\left(257^{\circ} \mathrm{F}\right)$.

system is divided into three phase fractions: the light phase (gas), the intermediate phase (liquid) and the heavy oil phase (liquid). The formation of a second liquid phase when propane or $\mathrm{CO}_{2}$ was used as solvent was observed by Feizabadi et al. [11]; claiming that the second liquid phase is mainly composed of the solvent itself.

\subsection{Modeling and Simulation Results}

With the objective of getting a monophasic fluid with a composition similar to that of the reservoir fluid, the PVTi simulation was performed on the recombined oil (obtained by mixing the first-stage separator gas and the stock-tank oil) at the reservoir saturation pressure and bottom hole temperature. Noting that the reported vapor-to-oil molar ratios for wells A\#22 and A\#33 are 0.5183 and 0.5603 , respectively.

The saturation pressure was obtained for each well at the reservoir conditions by tuning the PVTi simulator, which could not succeed in getting the required vapor phase composition, especially for methane, which has the highest percentage in the reservoir fluid. This might be attributed to the fact that we are using the gas available from the first-stage separator rather than the non-available late-stage separator gas. In order to solve such a problem, the monophasic fluid was reproduced by recombining the resulting gas phase from the PVTi simulator with the stock-tank oil.

The average of the absolute error (AAE) in composition between the fluid data and the reproduced monophasic fluid was $0.68 \%$ for well A\#22 and $0.99 \%$ for well A\#33, but still there is a high deviation in the methane content between the field and the reproduced data; $7.4 \%$ for well A\#22 and $11.0 \%$ for well A\#33. In order to minimize such deviation, the vapor-to-oil molar was adjusted in this work until a zero deviation in methane content was achieved for each reservoir monophasic fluid. The converged vapor-to-oil molar ratios were 0.4199 for well A\#22 and 0.4196 for well A\#33. The resulting average of the absolute errors (AAE) in composition after these trials became $0.79 \%$ for well A\#22 and 1.09\% for well A\#33. Figure 13 and Figure 14 show the compositional analysis for field data vs. recombined fluid at minimum average absolute errors in composition, and at $0 \%$ deviation in methane composition for wells $\mathrm{A} \# 22$ and A\#33, respectively.

On the other hand, Table 8 shows the experimental vs. predicted (using PVTpro) swelling saturation pressures for wells A\#22 and A\#33. The average of the absolute relative error (AARE) between experimental and predicted saturation pressures was 7.78\% for well A\#22 and 5.38\% for well A\#33. It is also clear from Table 8 that the saturation pressure of the system (at the specific reservoir bottom hole temperature) is highly affected by the $\mathrm{CO}_{2}$ mass fraction in the $\mathrm{CO}_{2}$ /live oil mixture and it is almost doubled upon increasing the $\mathrm{CO}_{2}$ mass fraction from 0.0 to 0.6 .

Table 9 shows the PVTpro predictions of the swelling saturation pressure for $\mathrm{CO}_{2}$ mass fractions above 0.6 . A phase transformation from saturated liquid (bubble) to saturated vapor (dew) was predicted at a $\mathrm{CO}_{2}$ mass

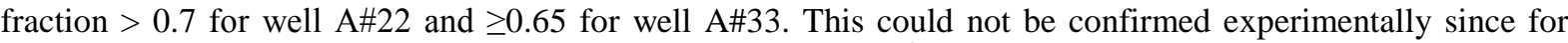
$w_{\mathrm{CO}_{2}}>0.6$ a pressure of more than $500 \mathrm{bar}$ is required in the $2^{\text {nd }}$ syringe pump, which is above the limit of that pump. Also at $w_{\mathrm{CO}_{2}}>0.6$ no stabilization was observed and no monophasic system was detected.

Lastly, the swelling test was performed using the PVTpro simulator and the predicted saturation pressures vs. $\mathrm{CO}_{2}$ mass fraction were compared with those obtained experimentally as shown in Figure 15. The average of 
Table 8. Experimental vs. simulated (using PVTpro) swelling saturation pressures for wells A\#22 and A\#33.

\begin{tabular}{|c|c|c|c|c|c|c|c|}
\hline \multicolumn{4}{|c|}{ Well A\#22 at $235^{\circ} \mathrm{F}$} & \multicolumn{4}{|c|}{ Well $\mathrm{A} \# 33$ at $257^{\circ} \mathrm{F}$} \\
\hline$w_{\mathrm{CO}_{2}}$ & $\begin{array}{c}P^{\text {sat }}, \\
\text { (Exp.), bar }\end{array}$ & $\begin{array}{c}P^{\text {sat }} \\
\text { (PVTpro), bar }\end{array}$ & AARE, $\%$ & $w_{\mathrm{CO}_{2}}$ & $\begin{array}{c}P^{\text {sat }} \\
\text { (Exp.), bar }\end{array}$ & $\begin{array}{c}P^{\text {sat }} \\
\text { (PVTpro), bar }\end{array}$ & AARE, \% \\
\hline 0.00 & 154.9 & 157.0 & 1.36 & 0.00 & 161.7 & 163.9 & 1.36 \\
\hline 0.05 & 167.2 & 166.2 & 0.60 & 0.05 & 178.0 & 173.9 & 2.30 \\
\hline 0.10 & 192.6 & 176.1 & 8.57 & 0.10 & 195.5 & 184.7 & 5.52 \\
\hline 0.15 & 205.9 & 186.7 & 9.32 & 0.15 & 212.0 & 196.7 & 7.22 \\
\hline 0.20 & 230.4 & 198.4 & 13.89 & 0.20 & 235.2 & 209.2 & 11.05 \\
\hline 0.25 & 242.6 & 211.4 & 12.86 & 0.25 & 248.3 & 223.6 & 9.95 \\
\hline 0.30 & 253.4 & 226.0 & 10.81 & 0.30 & 261.1 & 240.1 & 8.04 \\
\hline 0.35 & 267.0 & 242.9 & 9.03 & 0.35 & 277.3 & 259.3 & 6.49 \\
\hline 0.40 & 287.3 & 262.8 & 8.53 & 0.40 & 289.1 & 282.0 & 2.46 \\
\hline 0.50 & 317.1 & 316.0 & 0.35 & 0.50 & 324.0 & 340.6 & 5.12 \\
\hline \multirow[t]{2}{*}{0.60} & 357.4 & 394.0 & 10.24 & 0.60 & 400.0 & 420.7 & 5.18 \\
\hline & Average ARE & & 7.78 & & Average ARE & & 5.88 \\
\hline
\end{tabular}

Table 9. Predicted swelling saturation pressures (using PVTpro) for wells A\#22 and A\#33 at $w_{\mathrm{CO}_{2}}>0.6$.

\begin{tabular}{|c|c|c|c|c|c|}
\hline \multicolumn{3}{|c|}{ Well $\mathrm{A} \# 22$ at $235^{\circ} \mathrm{F}$} & \multicolumn{3}{|c|}{ Well A\#33 at $257^{\circ} \mathrm{F}$} \\
\hline$w_{\mathrm{CO}_{2}}$ injected & $P_{\text {bub, }}$ bar & $P_{\text {dew }}$, bar & $w_{\mathrm{CO}_{2}}$ injected & $P_{\text {bub }}$, bar & $P_{\text {dew, }}$ bar \\
\hline 0.65 & 446.2 & - & 0.65 & - & 471.8 \\
\hline 0.70 & 511.7 & - & 0.70 & - & 533.5 \\
\hline 0.75 & - & 597.5 & 0.75 & - & 610.4 \\
\hline
\end{tabular}

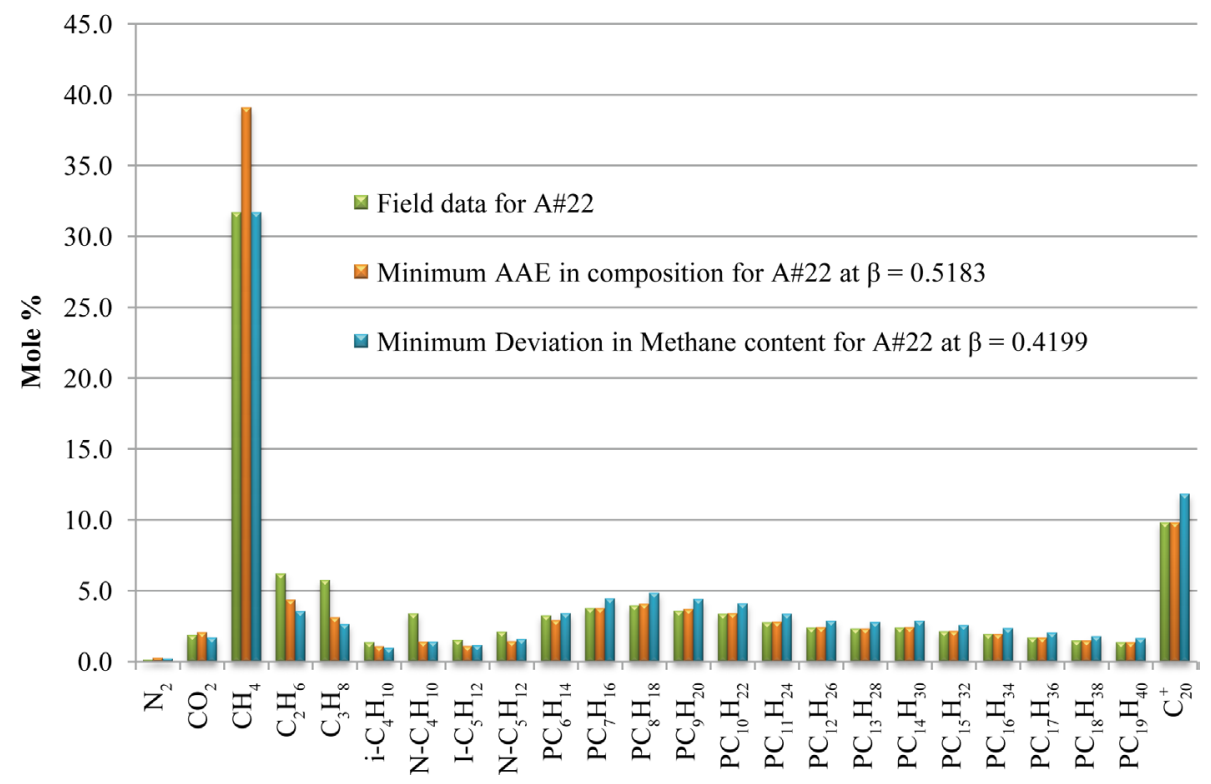

Figure 13. Compositional analysis for well A\#22: Field data vs. recombined fluid at $\beta=$ 0.5183 (minimum AAE in composition) and recombined fluid at $\beta=0.4199(0 \%$ deviation in methane composition). 


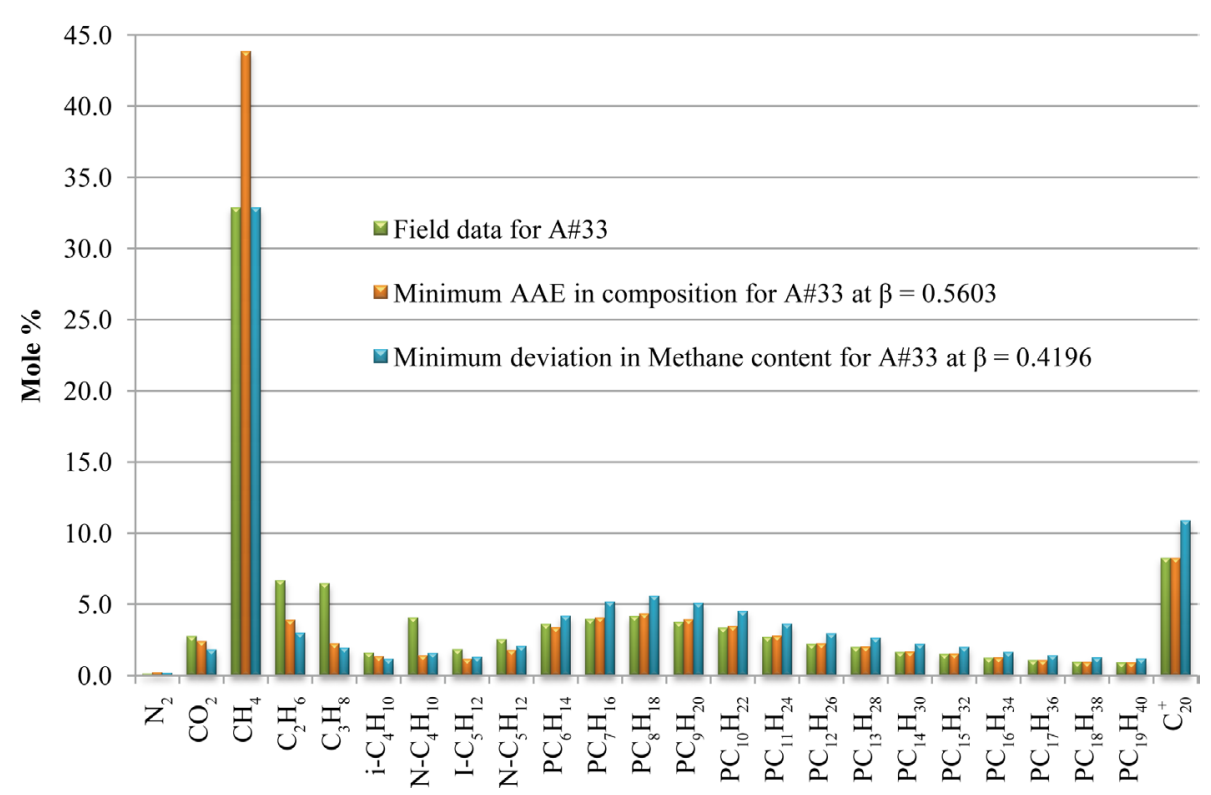

Figure 14. Compositional analysis for well A\#33: Field data vs. recombined fluid at $\beta=$ 0.5603 (minimum AAE in composition) and recombined fluid at $\beta=0.4196$ ( $0 \%$ deviation in methane composition).

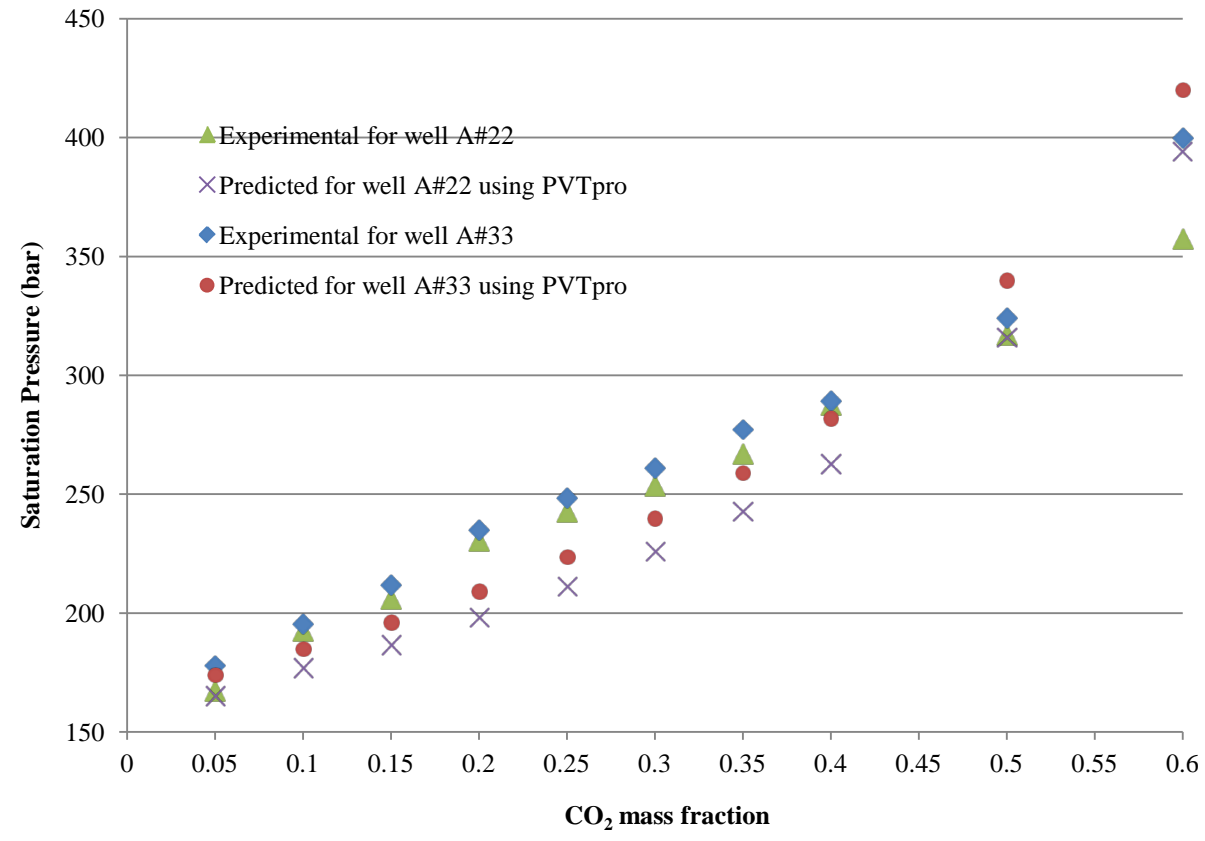

Figure 15. Experimental vs. predicted swelling saturation pressure vs. $\mathrm{CO}_{2}$ mass fraction for wells A\#22 and A\#33.

the absolute relative error (AARE) was 7.78\% for well A\#22 and 5.38\% for well A\#33 as confirmed in Table 8 above.

\section{Conclusion}

In this work an experimental phase equilibrium setup for the recombination of live oil (stock-tank oil and firststage separator gas) and measurement of the corresponding phase behaviors of $\mathrm{CO}_{2}$ /live oil mixtures is described. The experimental setup has been successfully tested in two sets of recombination tests followed by 
swelling tests for various $\mathrm{CO}_{2}$ mass fractions. The $\mathrm{CO}_{2}$ /live oil system was studied at the reservoir bottom hole temperature and at high pressure ranges starting at the reservoir saturation pressures of two United Arab Emi-

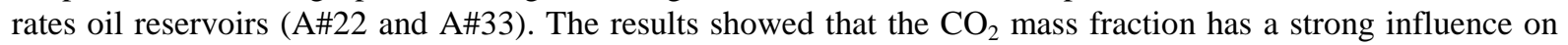
the swelling saturation pressure and the swelling factors of the systems under study. The swelling saturation pressure has almost doubled and the swelling factor has increased from 1.0 to 1.74 upon the increase of the injected $\mathrm{CO}_{2}$ mass fraction from 0.0 to 0.6. In general, the higher the swelling factor the better the enhanced oil recovery (EOR). Also it has been noticed that three-phase (liquid-liquid-vapor) transitions were observed at $\mathrm{CO}_{2}$ mass fraction of 0.3 and above. This might have a positive effect on enhanced oil recovery.

\section{References}

[1] Patil, S., Dandekar, A. and Khataniar, S. (2008) Phase Behavior, Solid Organic Precipitation, and Mobility Characterization Studies in Support of Enhanced Heavy Oil Recovery on the Alaska North Slope. DOE Award No.: DE-FC2601NT41248. Prepared for US Department of Energy, National Energy Technology Laboratory, Submitted by Petroleum Development Laboratory Institute of Northern Engineering, University of Alaska Fairbanks. http://dx.doi.org/10.2172/963365

[2] Moortgat, J., Firoozabadi, A., Li, Z. and Espósito, R. (2013) $\mathrm{CO}_{2}$ Injection in vertical and horizontal cores: Measurements and numerical simulation. SPE Journal, 18, 1-14. http://dx.doi.org/10.2118/135563-PA

[3] Danesh, A. (1998) PVT and Phase Behaviour of Petroleum Reservoir Fluids, Developments in Petroleum Science. Elsevier Science, 47.

[4] Mathiassen, O.M. (2003) $\mathrm{CO}_{2}$ as Injection Gas for Enhanced Oil Recovery and Estimation of the Potential on the Norwegian Continental Shelf. M.Sc. Thesis, Norwegian University of Science \& Technology (NTNU), Trondheim/ Stavanger, Part I of II.

[5] Yuan, S., Ye, J. and Sun, Z. (2003) Theory and Practice in Gas-Condensate Reservoir Development. China Petroleum Industry Press, Beijing.

[6] Wang, S., Chen, S. and Li, Z. (2016) Characterization of Produced and Residual Oils in the $\mathrm{CO}_{2}$ Flooding Process. Energy Fuels, 30, 54-62. http://dx.doi.org/10.1021/acs.energyfuels.5b01828

[7] Pedersen, K.S., Fredenslund, A. and Thomassen, P. (1989) Properties of Oils and Natural Gases. Gulf Publ. Co., Houston.

[8] Araujo, C.B.K., Capitelli, F.O., Rajagopal, K., Corazza, M.L. and Ndiaye, P.M. (2012) Phase Behavior of Brazilian Stock-Tank Oil and Carbon Dioxide at Reservoir Conditions: Experiments and Thermodynamic Modeling. IX Iberoamerican Conference on Phase Equilibria and Fluid Properties for Process Design (EquiFase 2012), Puerto Varas, 8-12 October 2012.

[9] Al-Jarba, M. and Al-Anazi, B.D. (2009) A Comparison Study of the of the $\mathrm{CO}_{2}$-Oil Physical Properties Literature Correlations Accuracy Using Visual Basic Modelling Technique. NAFTA, 60, 287-291.

[10] Emera, M.K. and Sarma, H.K. (2006) Genetic Algorithm (GA)-Based Correlations Offer More Reliable Prediction of $\mathrm{CO}_{2}$-Oil Physical Properties. Canadian International Petroleum Conference, Calgary, 13-15 June 2006. http://dx.doi.org/10.2118/2006-197

[11] Feizabadi, S.A., Abedi, J. and Chen, Z. (2012) Importance of a Second Liquid Phase Formation in $\mathrm{CO}_{2}$ Injection into Bitumen Reservoirs and Its Effect on Production. SPE Improved Oil Recovery Symposium, Tulsa, 14-18 April 2012. http://dx.doi.org/10.2118/153712-ms

[12] CSLF Task Force (2013) Technical Challenges in the Conversion of $\mathrm{CO}_{2}$-EOR Projects to $\mathrm{CO}_{2}$ Storage Projects. Final Report, Carbon Sequestration Leadership Forum, September.

[13] Mohammad, R.S. (2012) PVT Study of Selected UAE Reservoir Fluids. M.Sc. Thesis, UAE University, Al Ain.

[14] Brill, J.P. and Beggs, H.D. (1974) Two-Phase Flow in Pipes. University of Tulsa, INTERCOMP Course, The Hague.

[15] Rojey, A., Jaffrey, C., Cornot-Gandolphe, S., Durand, B., Jullian, S. and Vallais, M. (1997) Natural Gas. Production, Processing, Transport, Éditions Technip, Paris, 429 p.

[16] Angus, S., Armstrong, B., de Reuck, K.M., Altunin, V.V., Gadetskii, O.G., Chapela, G.A. and Rowlinson, J.S. (1976) International Union of Pure and Applied Chemistry (IUPAC). Carbon Dioxide: International Thermodynamic Tables of the Fluid State, Vol. 3, Pergamon Press, Oxford, 1522-2640.

[17] Kokal, S.L. and Sayegh, S.G. (1990) Gas-Saturated Bitumen Density Predictions Using the Volume-Translated PengRobinson Equation of State. Journal of Canadian Petroleum Technology, 29, 77-82. http://dx.doi.org/10.2118/90-05-07

[18] Lielmezs, J., Howell, S.K. and Campbell, H.D. (1983) Modified Redlich-Kwong Equation of State for Saturated Va- 
por-Liquid Equilibrium. Chemical Engineering Science, 38, 1293-1301. http://dx.doi.org/10.1016/0009-2509(83)80049-9

[19] Peng, D.Y. and Robinson, D.B. (1976) A New Two Constant Equation of State. Industrial and Engineering Chemistry, Fundamentals, 15, 59-64. http://dx.doi.org/10.1021/i160057a011

[20] Peneloux, A., Rauzy, E. and Freze, R. (1982) A Consistent Correction for Redlich-Kwong-Soave Volumes. Fluid Phase Equilibria, 8, 7-23. http://dx.doi.org/10.1016/0378-3812(82)80002-2

[21] Katz, D.L. and Firoozabadi, A. (1978) Predicting Phase Behavior of Condensate/Crude Oil Systems Using Methane Interaction Coefficients. Journal of Petroleum Technology, 30, 1649-1655. http://dx.doi.org/10.2118/6721-PA

[22] Chueh, P.L. and Prausnitz, J.M. (1968) Calculation of High-Pressure Vapor-Liquid Equilibria. Industrial \& Engineering Chemistry, 60, 34-52. http://dx.doi.org/10.1021/ie50699a007 


\title{
Nomenclature
}

a Attraction parameter in the PR EOS

$a_{c} \quad$ A parameter defined by Equation (12) in the PR EOS

$b \quad$ Repulsion parameter in the PR EOS

$c_{i} \quad$ Volume-shift parameter

$m \quad$ A parameter defined by Equation (13) in the PR EOS

$P_{c} \quad$ Critical pressure

$P_{c m} \quad$ Mixture critical pressure

$P_{p r} \quad$ Pseudo-reduced pressure, dimensionless

$P_{r} \quad$ Reduced pressure, dimensionless

$P^{\text {sat }} \quad$ Saturation pressure

$P_{s t} \quad$ Pressure at standard conditions

$R \quad$ Universal gas constant

$s_{i} \quad$ Dimensionless volume-shift parameter

$T_{c} \quad$ Critical temperature

$T_{c m} \quad$ Mixture critical temperature

$T_{p r} \quad$ Pseudo-reduced temperature, dimensionless

$T_{\text {res }} \quad$ Reservoir bottom hole temperature

$T_{r} \quad$ Reduced temperature, dimensionless

$T_{s t} \quad$ Temperature at standard conditions

$v \quad$ Molar volume in the PR EOS

$V^{0} \quad$ Volume of saturated live oil, $\mathrm{ml}$

$V^{01} \quad$ Volume of the saturated $\mathrm{CO}_{2}$ /live oil mixture, $\mathrm{ml}$

Vi Valve number $i$ (= 1 to 6$)$ in the experimental setup

$V_{i} \quad$ Initial volume of $\mathrm{CO}_{2}$ in the $2^{\text {nd }}$ syringe pump, $\mathrm{ml}$

$V_{f} \quad$ Final volume of $\mathrm{CO}_{2}$ in the $2^{\text {nd }}$ syringe pump, $\mathrm{ml}$

$V^{0} \quad$ Volume of live oil system (recombination test), $\mathrm{ml}$

$V^{01} \quad$ Volume of $\mathrm{CO}_{2} /$ live oil system (swelling test), $\mathrm{ml}$

$V^{\text {sw }} \quad$ Swelling factor

$x \quad$ Liquid mole fraction

$y \quad$ Vapor mole fraction

z $\quad$ Mole fraction (liquid or vapor)

Z Compressibility factor

\section{Greek Symbols}

$k_{i j} \quad$ Binary interaction parameter between components $i$ and $j$

$\omega$ Acentric factor

\section{Abbreviations}

\author{
AARE Average of Absolute Relative Errors \\ EOR Enhanced Oil Recovery \\ PR Peng-Robinson \\ SRK Soave-Redlich-Kwong
}




\section{Appendix}

Table A1. Critical properties and composition of the gas mixture of wells $\mathrm{A} \# 22$ and $\mathrm{A \# 33.}$

\begin{tabular}{cccccc}
\hline \multirow{2}{*}{ Component } & \multicolumn{2}{c}{ Critical Properties } & & \multicolumn{2}{c}{ Mole fraction, $y_{i}$} \\
\cline { 2 - 3 } \cline { 5 - 6 } $\mathrm{N}_{2}$ & $P_{\mathrm{c}}$, bar & $T_{\mathrm{c}}, \mathrm{K}$ & & Well A\#22 & Well A\#33 \\
$\mathrm{CO}_{2}$ & 33.9 & 126.2 & & 0.0049 & 0.0035 \\
$\mathrm{C}_{1}$ & 73.9 & 304.7 & & 0.0396 & 0.0426 \\
$\mathrm{C}_{2}$ & 46.0 & 190.6 & & 0.7539 & 0.7820 \\
$\mathrm{C}_{3}$ & 48.8 & 305.4 & & 0.0824 & 0.0672 \\
$\mathrm{i}-\mathrm{C}_{4}$ & 42.5 & 369.8 & & 0.0543 & 0.0318 \\
$\mathrm{n} \mathrm{C}_{4}$ & 36.5 & 408.1 & & 0.0173 & 0.0193 \\
$\mathrm{i}-\mathrm{C}_{5}$ & 38.0 & 425.2 & & 0.0143 & 0.0089 \\
$\mathrm{n} \mathrm{C}_{5}$ & 33.9 & 460.4 & 0.0082 & 0.0070 \\
$\mathrm{C}_{6}$ & 33.7 & 469.6 & 0.0061 & 0.0090 \\
$\mathrm{C}_{7}^{+}$ & 30.1 & 507.5 & 0.0051 & 0.0087 \\
\hline
\end{tabular}

Table A2. Values of the volume-shift parameters calculated by the PVTi simulator.

\begin{tabular}{ccc}
\hline Component & s-Shifts & c-shifts $\left(\mathrm{ft}^{3} / \mathrm{lb}-\mathrm{mol}\right)$ \\
\hline $\mathrm{N}_{2}$ & -0.0131 & -0.0506 \\
$\mathrm{CO}_{2}$ & -0.0427 & -0.0183 \\
$\mathrm{C}_{1}$ & -0.0144 & -0.0619 \\
$\mathrm{C}_{2}$ & -0.1033 & -0.0669 \\
$\mathrm{C}_{3}$ & -0.0775 & -0.0699 \\
$\mathrm{iC}_{4}$ & -0.0620 & -0.0719 \\
$\mathrm{nC}_{4}$ & -0.0542 & -0.0629 \\
$\mathrm{iC}_{5}$ & -0.0418 & -0.0588 \\
$\mathrm{nC}_{5}$ & -0.0303 & -0.0437 \\
$\mathrm{C}_{6}$ & -0.0073 & -0.0127 \\
$\mathrm{C}_{7}$ & 0.0576 & 0.1113 \\
$\mathrm{C}_{8}$ & 0.0319 & 0.0661 \\
$\mathrm{C}_{9}$ & 0.0595 & 0.1412 \\
$\mathrm{C}_{10}$ & 0.0861 & 0.2308 \\
$\mathrm{C}_{11}$ & 0.1140 & 0.3431 \\
$\mathrm{C}_{12}$ & 0.1280 & 0.4259 \\
$\mathrm{C}_{13}$ & 0.1384 & 0.5027 \\
$\mathrm{C}_{14}$ & 0.1417 & 0.5572 \\
$\mathrm{C}_{15}$ & 0.1471 & 0.6268 \\
$\mathrm{C}_{16}$ & 0.1553 & 0.7176 \\
$\mathrm{C}_{17}$ & 0.1578 & 0.7762 \\
$\mathrm{C}_{18}$ & 0.1570 & 0.8154 \\
$\mathrm{C}_{19}$ & 0.1600 & 3.1170 \\
$\mathrm{C}_{20}^{+}$ & 0.3052 & \\
& & 0.8713 \\
\hline & & \\
\hline
\end{tabular}

